\title{
A New Life
}

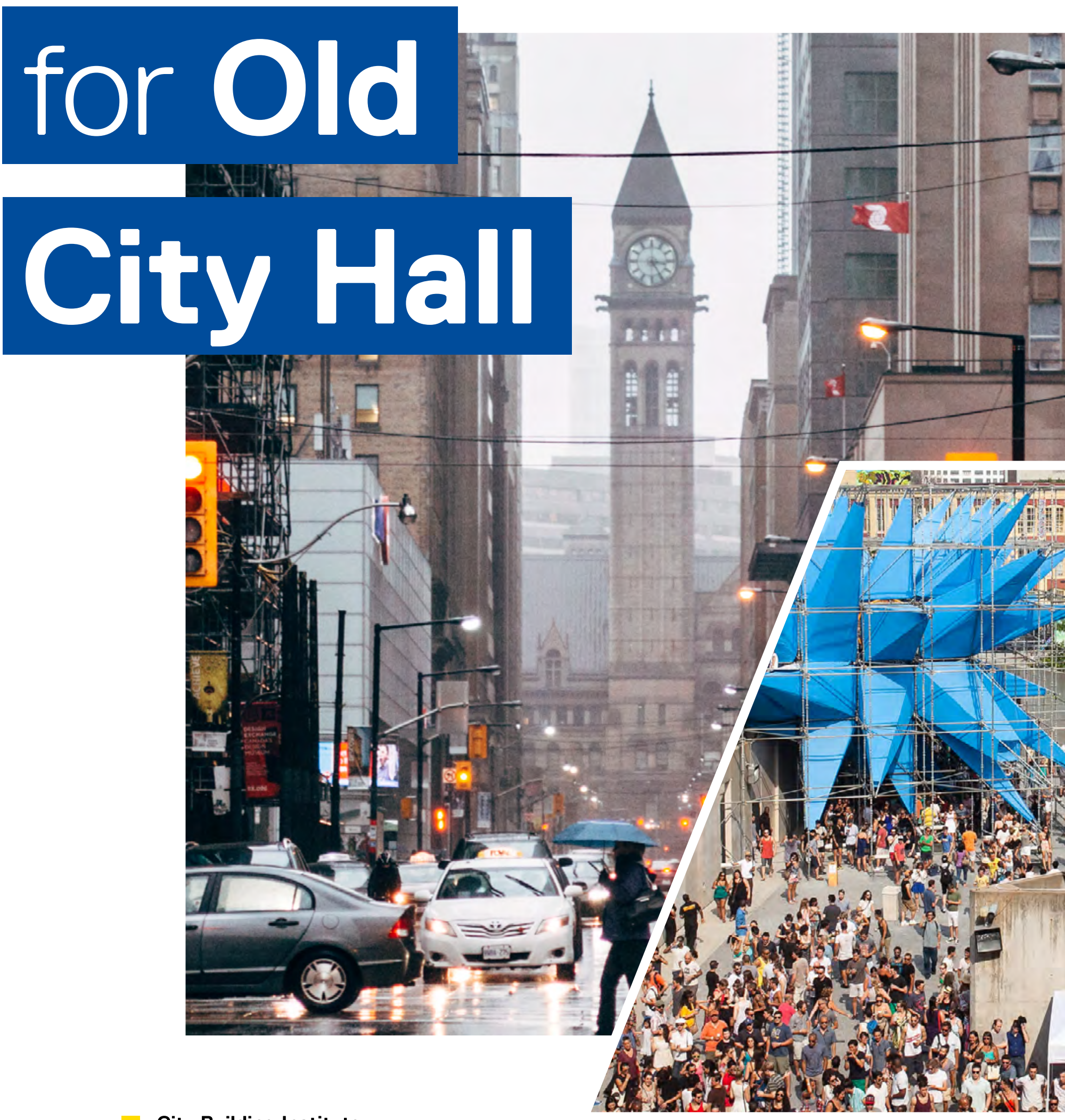




\section{CONTENTS}

$4 \quad$ A New Life for Old City Hall

6 Part One:

A Museum for the City

10 Museum of the City of New York

14 Canadian Centre for Architecture

18 Berlin Senate Department for Urban Development and the Environment

22 Design Exchange

26 Part Two:

New Ideas for Old Buildings

30 One Spadina

Crescent

34 The Theatre

Centre

38 MoMA PS1

42 The Royal Conservatory of Music

$46 \quad$ Endnotes

$48 \quad$ Image Credits

49 Acknowledgements

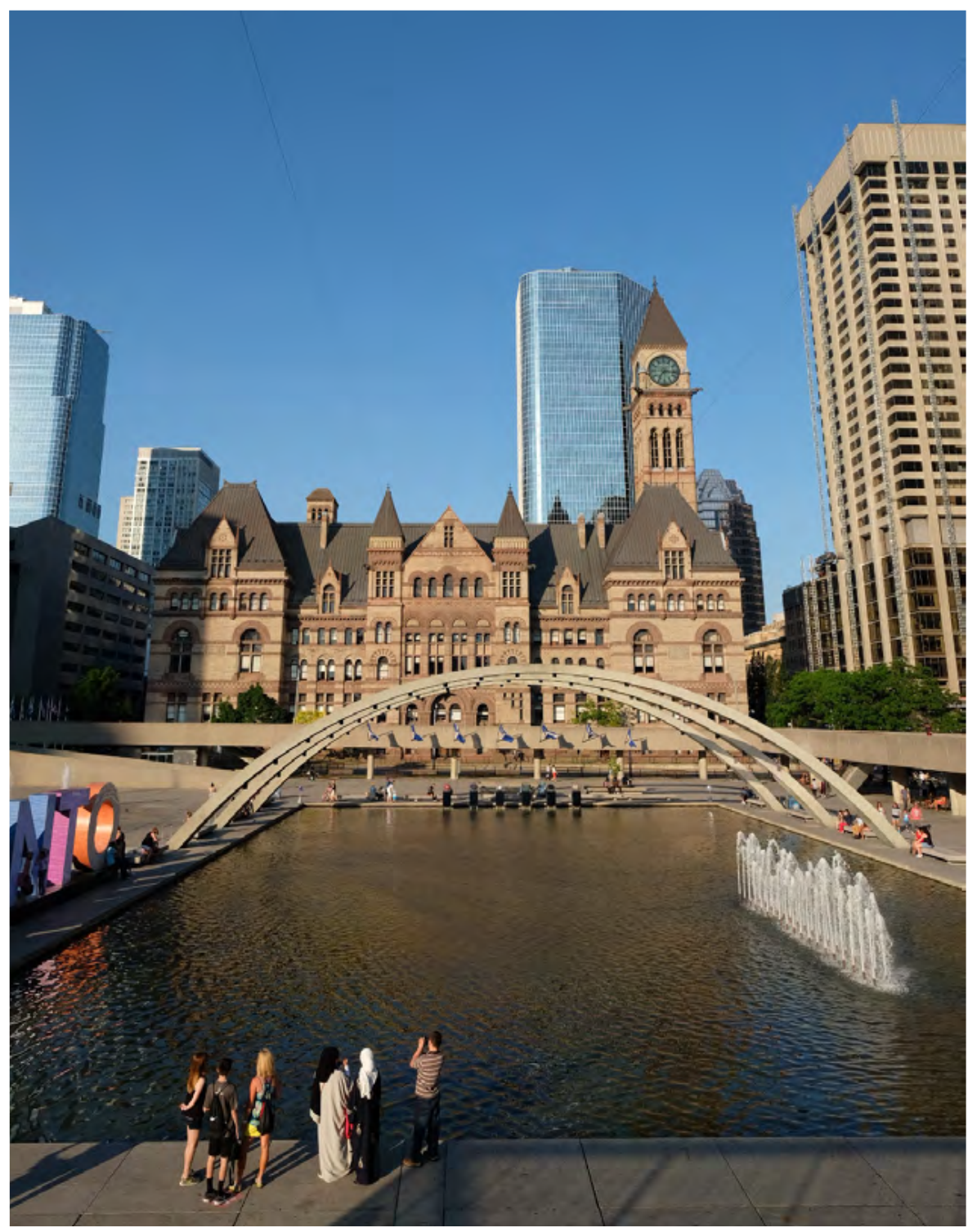

Old City Hall 
In 2015, City of Toronto staff embarked on a study to determine future uses for Old City Hall, a beloved landmark in the heart of Canada's largest city. The study will focus on accommodating a city museum and designing a public space that contributes to Toronto's cultural identity and civic life. ${ }^{1}$ As part of this process, the City will consult with stakeholders and the public to gather input and ideas on Old City Hall's future programming.

This report, A New Life for Old City Hall, does not put forth recommendations, but intends to spark creative thinking and inspire a public discussion around future uses for Old City Hall by presenting inspiring case studies, found locally and across the globe.

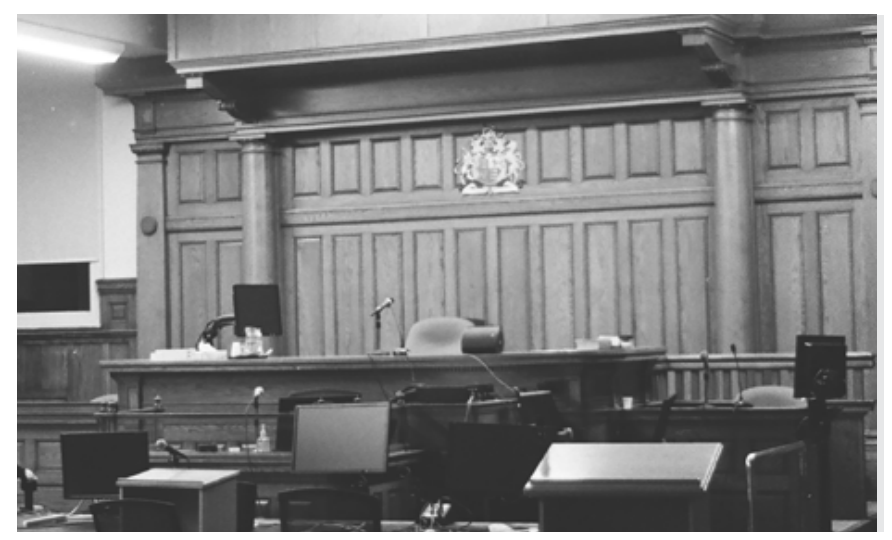

Old City Hall Courthouse 


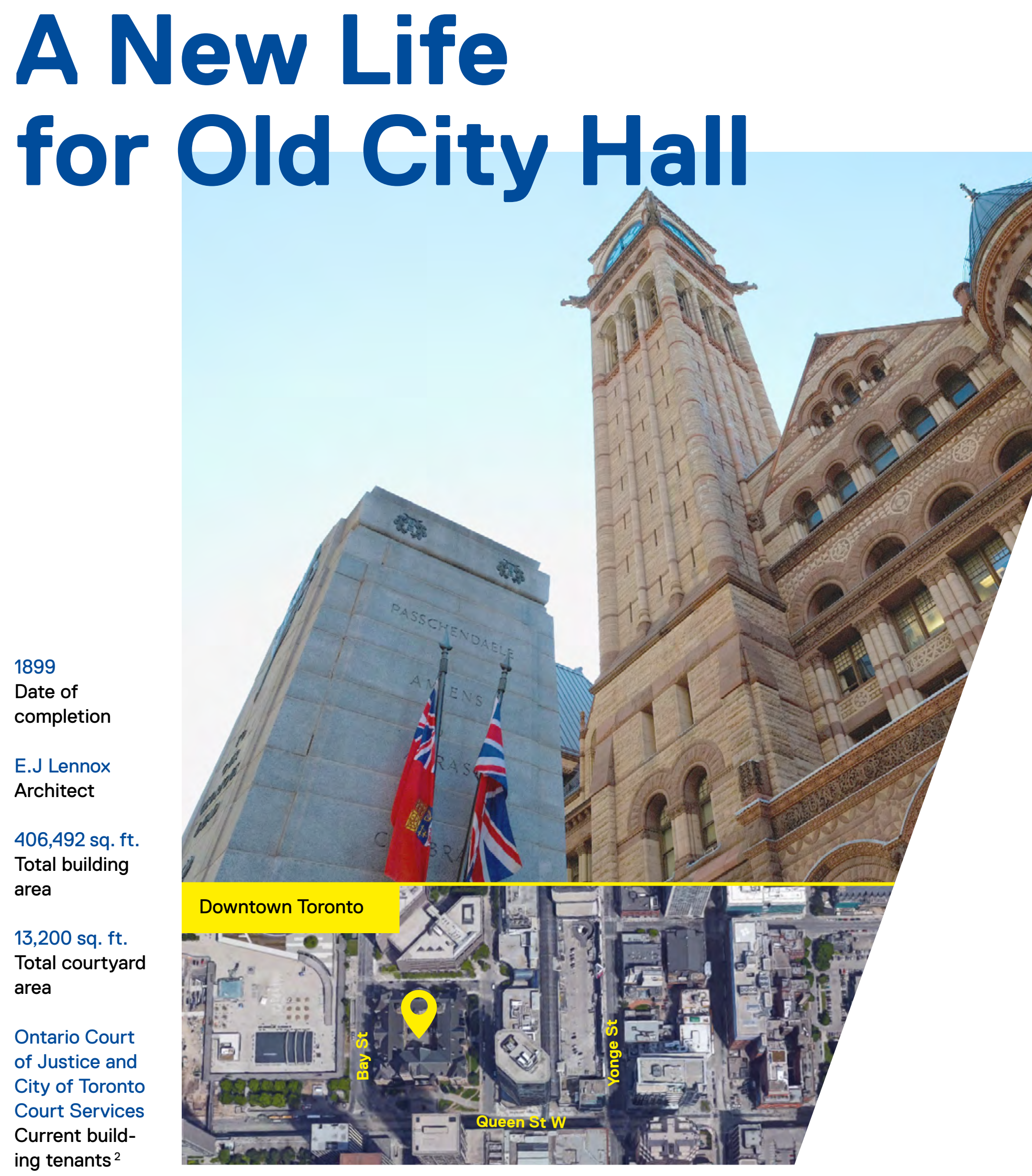


Two challenges for Old City Hall: The City of Toronto must consider how to repurpose a historic and iconic building for a variety of potential public, private, and civic uses. In addition, the City must also consider how a city museum could be incorporated into the space.

This report examines two sets of case studies:

1. A museum for the city: Examples of creatively programmed city museums that illuminate a city's past and engage with its present.

2. New ideas for old buildings: Iconic buildings that have been repurposed to accommodate exciting new uses, but continue to respect and pay homage to their historic design and function.

Not all repurposed buildings featured here are adapted to accommodate a museum, and not all city museums are housed in iconic buildings. But Toronto's Old City Hall ambitiously aims to achieve both. 


\section{Part One}
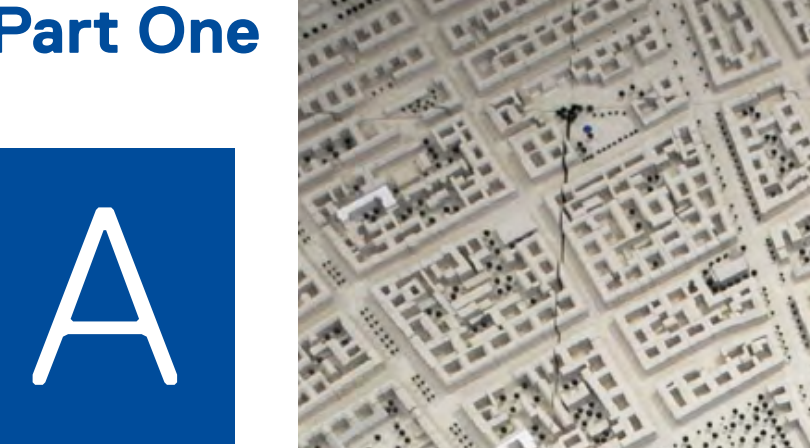

ats,

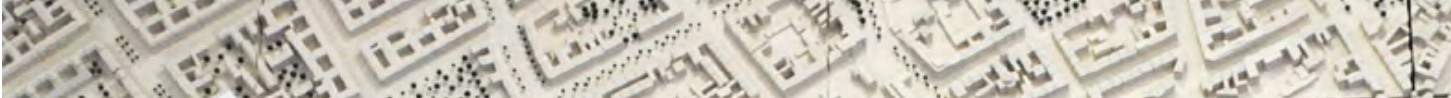

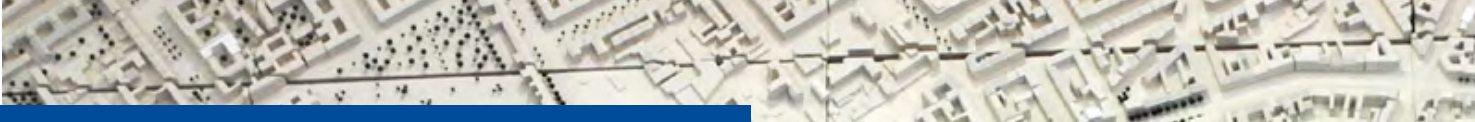

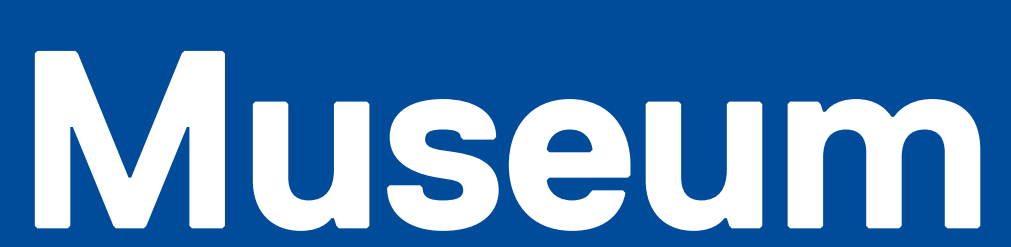

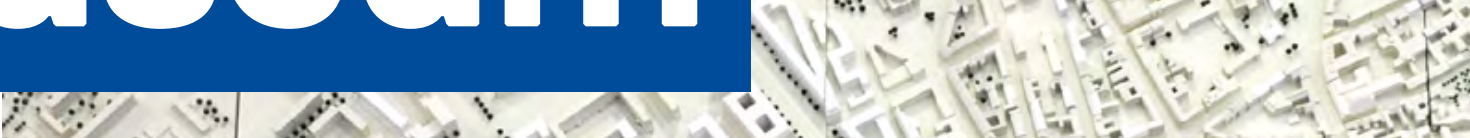

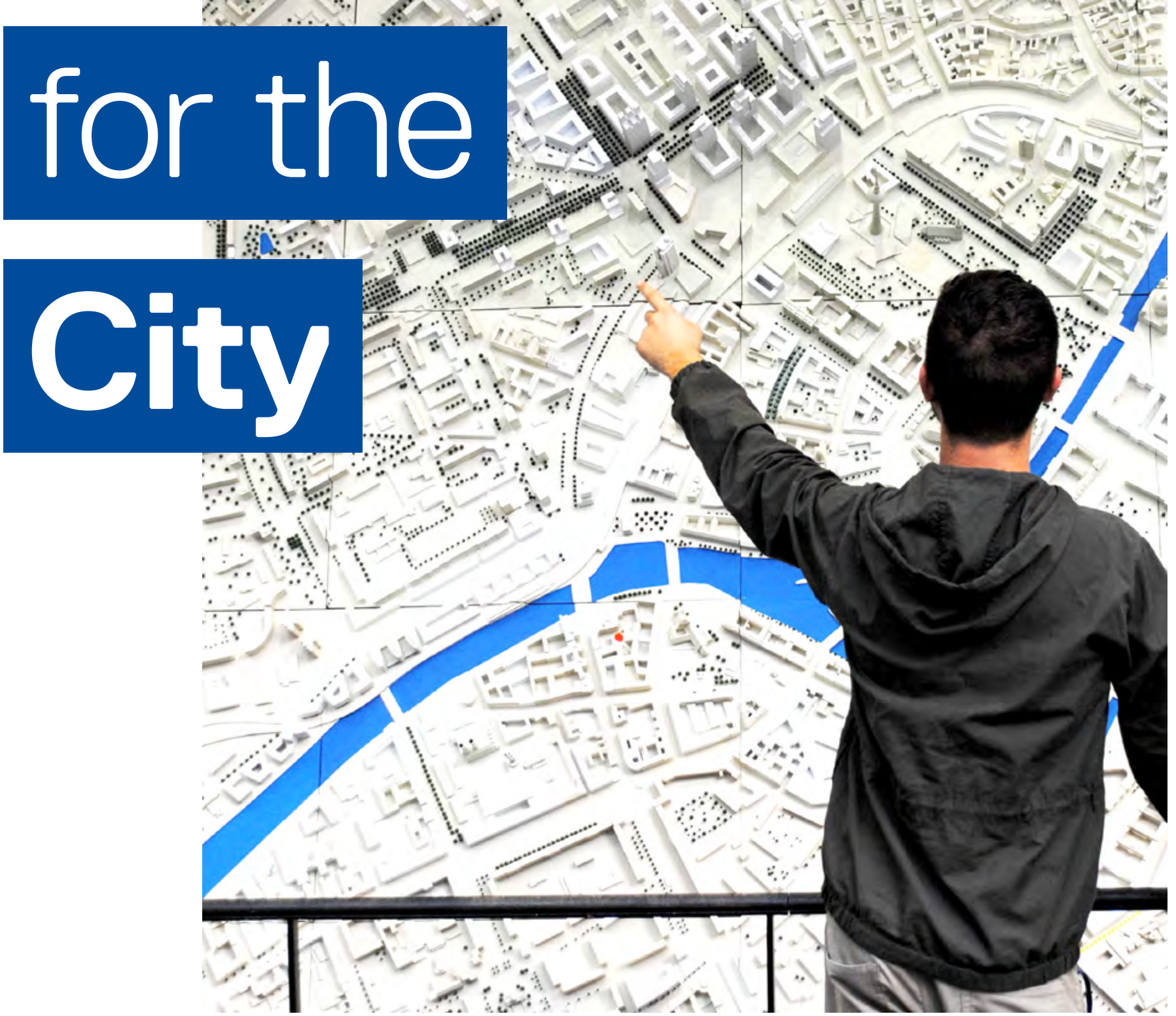

Berlin Senate Department for Urban Development and the Environment 
An exciting, interactive, and community-focused city museum would allow Torontonians to celebrate our shared history and participate in conversations about our future. It would serve as a living, breathing entity that reflects ongoing histories made in the city each day.

Toronto remains one of the few major urban centres without a dedicated city museum. ${ }^{3}$ Old City Hall's strategic location and historical significance make it an exciting site for a city museum and would position it as part of the civic commons, inviting the public back inside. But how can a Toronto museum located in Old City Hall move beyond a static collection of artifacts and provide adynamic platform for public life and participation?

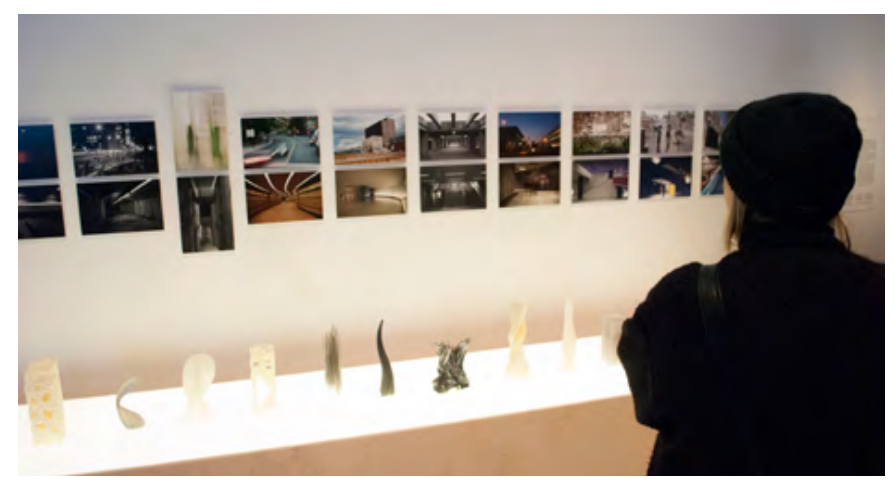

Canadian Centre for Architecture 
Local

and Global

Examples:

\section{Case Studies}

A city museum can take many forms - some are repositories of archival materials, while others bring present-day issues of civic importance to life. Some invite visitors to look, listen, and learn, while others engage residents in a dynamic dialogue while allowing for active participation and interpretation.

The following case studies focus on city museums that

engage in a range of programming, rather than simply archiving historical artifacts. By highlighting the programs, events, and exhibits that bring these city museums to life, these case studies demonstrate how organizations can connect with their audiences and with the city itself. How do these museums stay relevant to diverse visitors? What lessons can we learn and apply to a city museum for Toronto?
Museum of the City of New York

Canadian Centre for Architecture, Montreal

Berlin Senate Department for Urban Development and the Environment

Design Exchange, Toronto

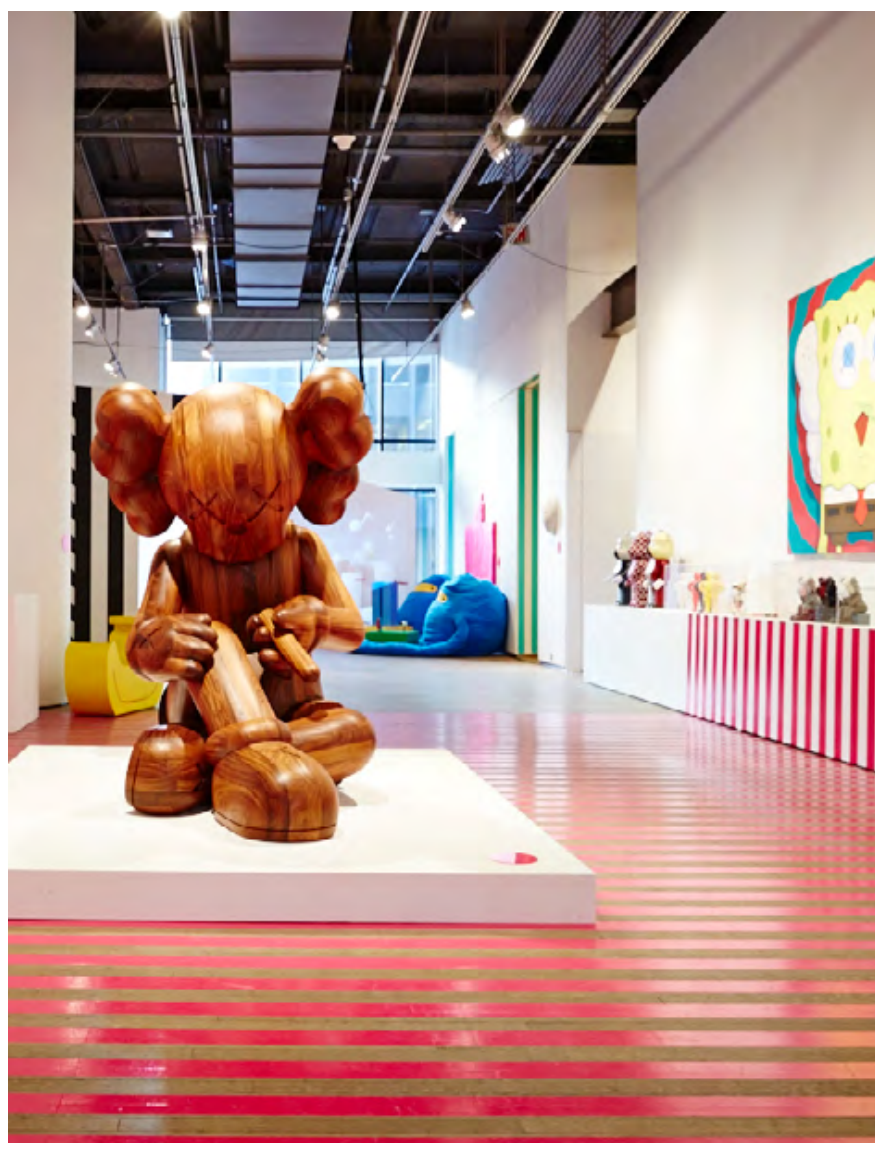

Design Exchange

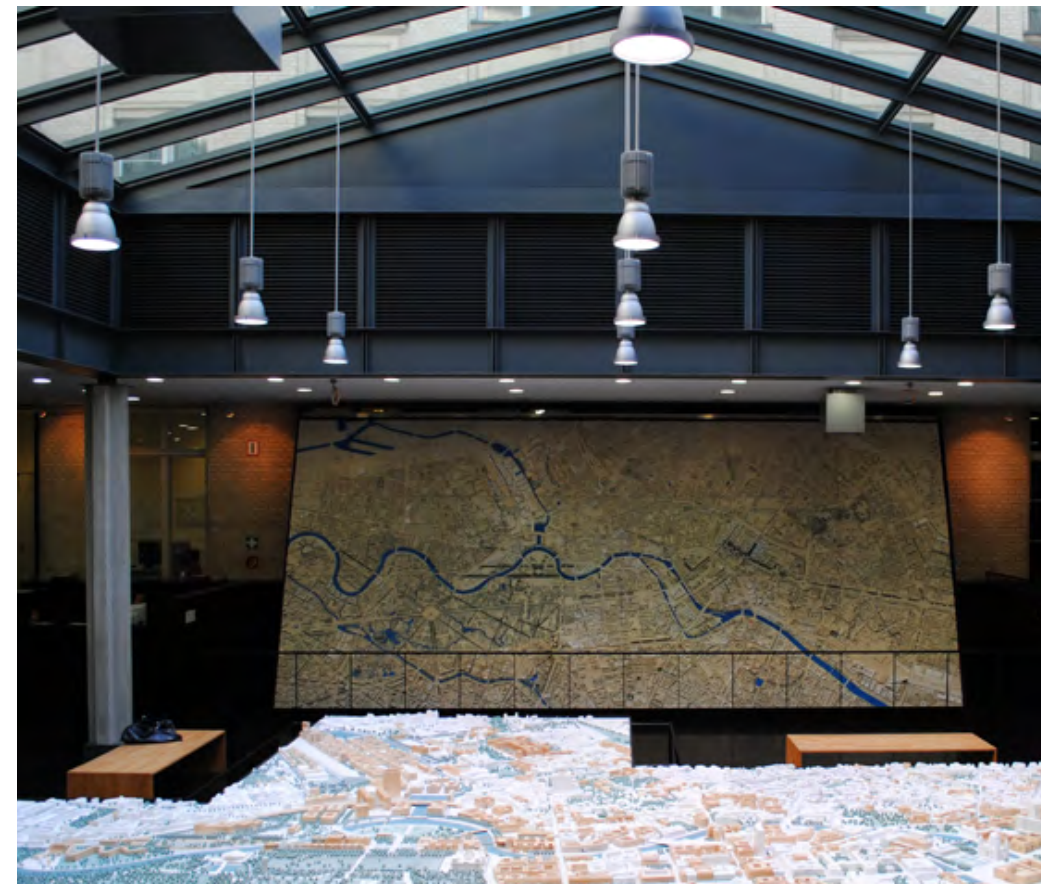

Berlin Senate Department for Urban Development and the Environment 


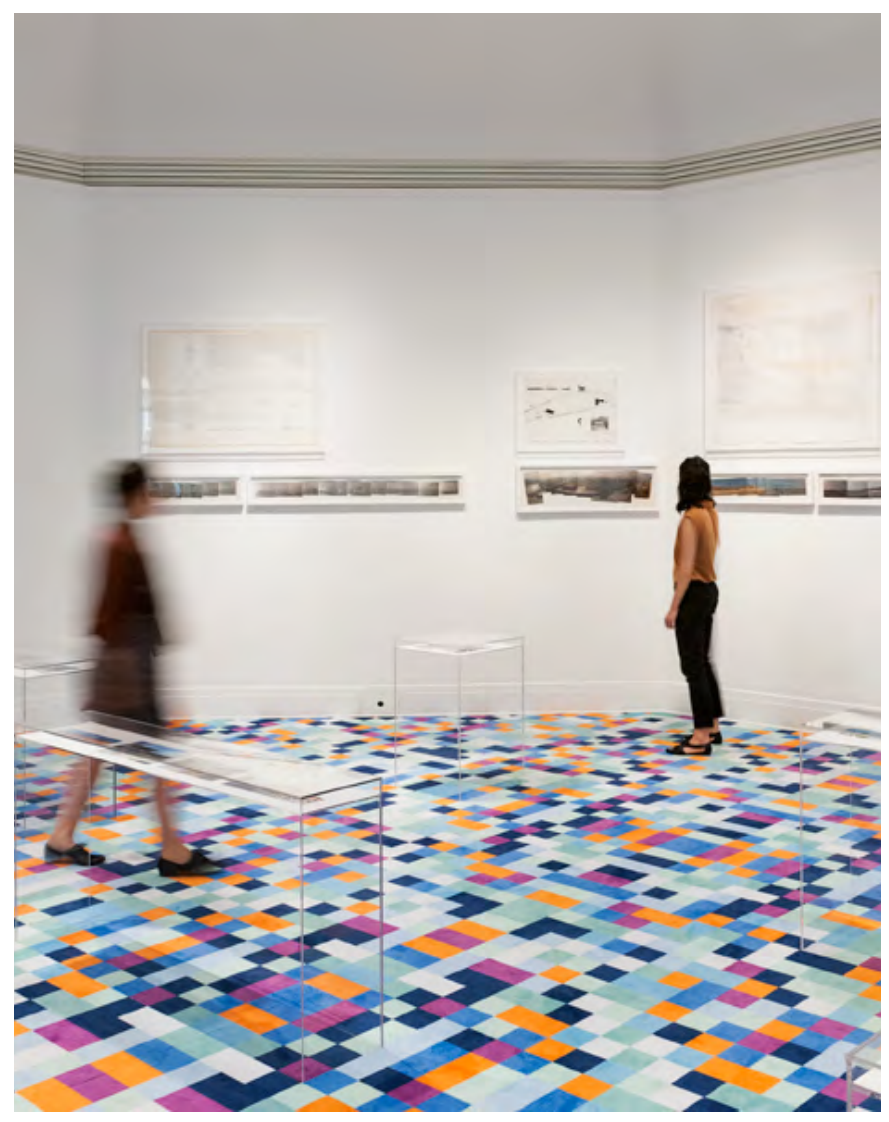

Canadian Centre for Architecture

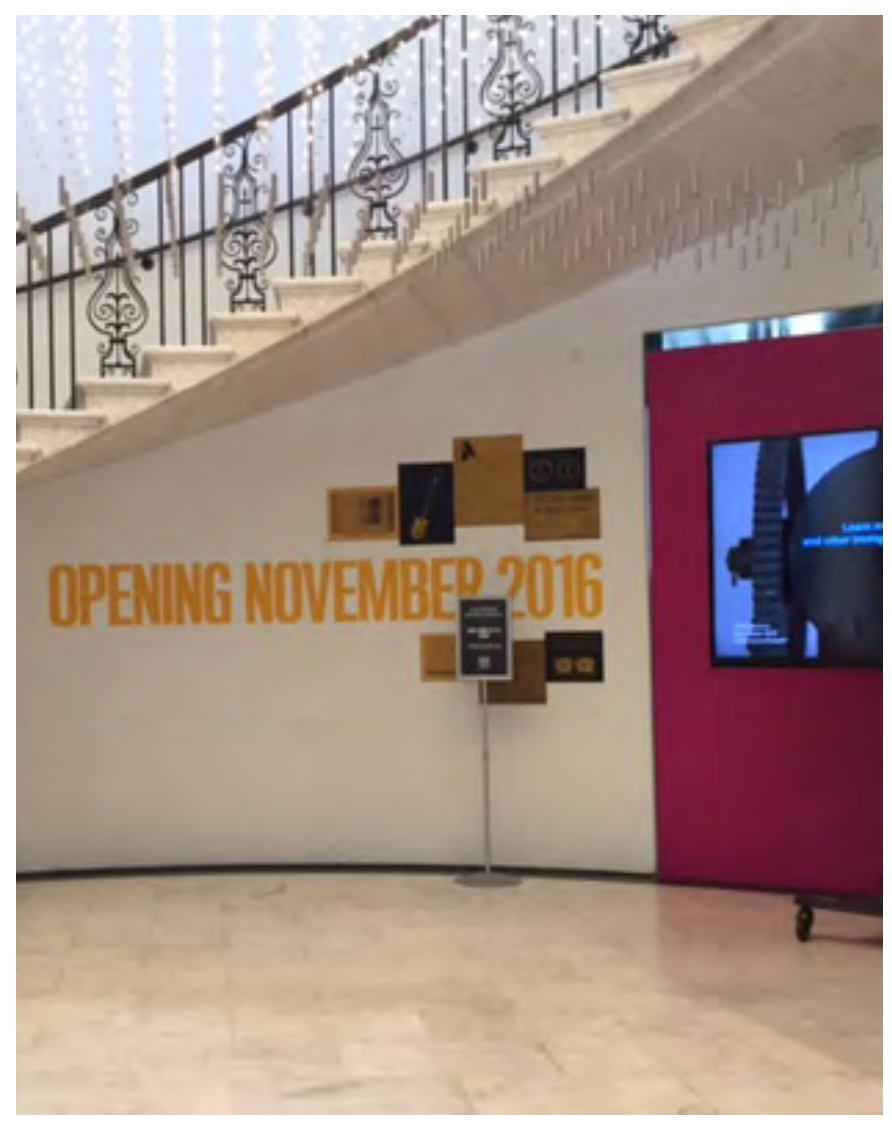

Museum of the City of New York

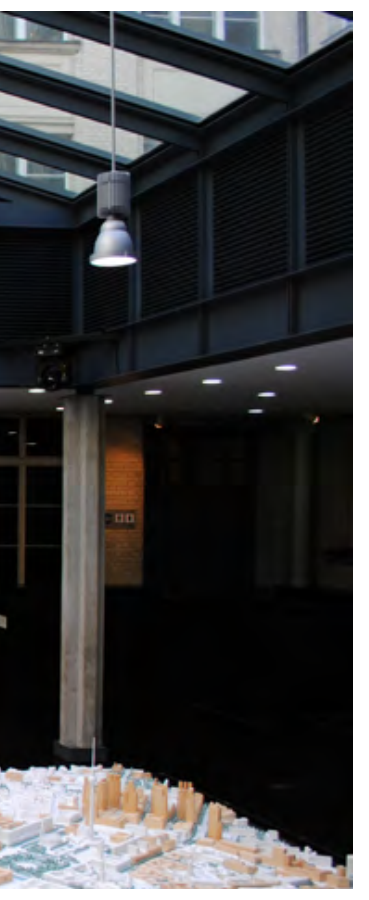

\section{Programming Legend}

Throughout the report, the following symbols identify specific types of programming for each case study:

- Cafe/Restaurant/Retail

@̈) Exhibits/Research

Public Programs/Special Events

Public Space

Venue/Event Space 


\section{Museum of the City of New York}

\section{The Museum of the City of New} York showcases the dynamic past, present, and future of New York City and its people.

1923

MCNY founded by Henry

Collins Brown

1932

MCNY moves into current building on $5^{\text {th }}$ Avenue

\$96 million Invested in Modernization and Expansion Project

$425,000+$

Visitors in 2014

750,000

Objects in the Museum's collection ${ }^{4}$

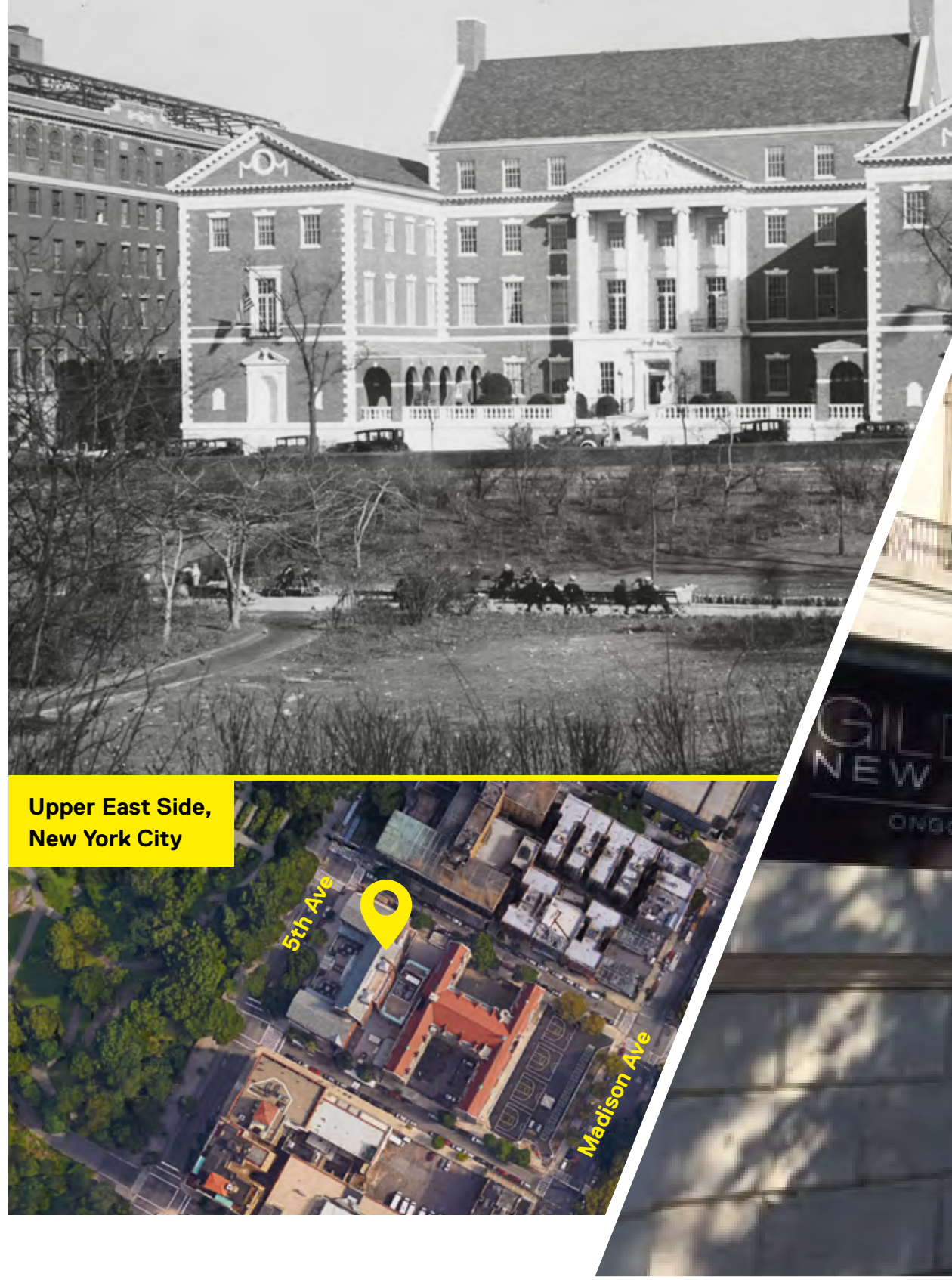




\section{Operating Structure}

The Museum of the City of

New York is a private nonprofit organization, governed by a board of trustees.

\section{Financial Structure}

The Museum's funding stream comprises a combination of contributions and earnings, including contributed income and services, special events, earned income through tickets and sales, and in-kind contributions. Space rentals for special events contribute significant earnings to the Museum. While general entrance fees are charged to visitors, the Museum grants free admission to educators, some post-secondary students, City employees, and others. ${ }^{8}$

The majority of the Museum's annual expenses are related to programming and exhibits. Fundraising, general administration, and capital expenses account for a smaller portion of its annual expenditures.

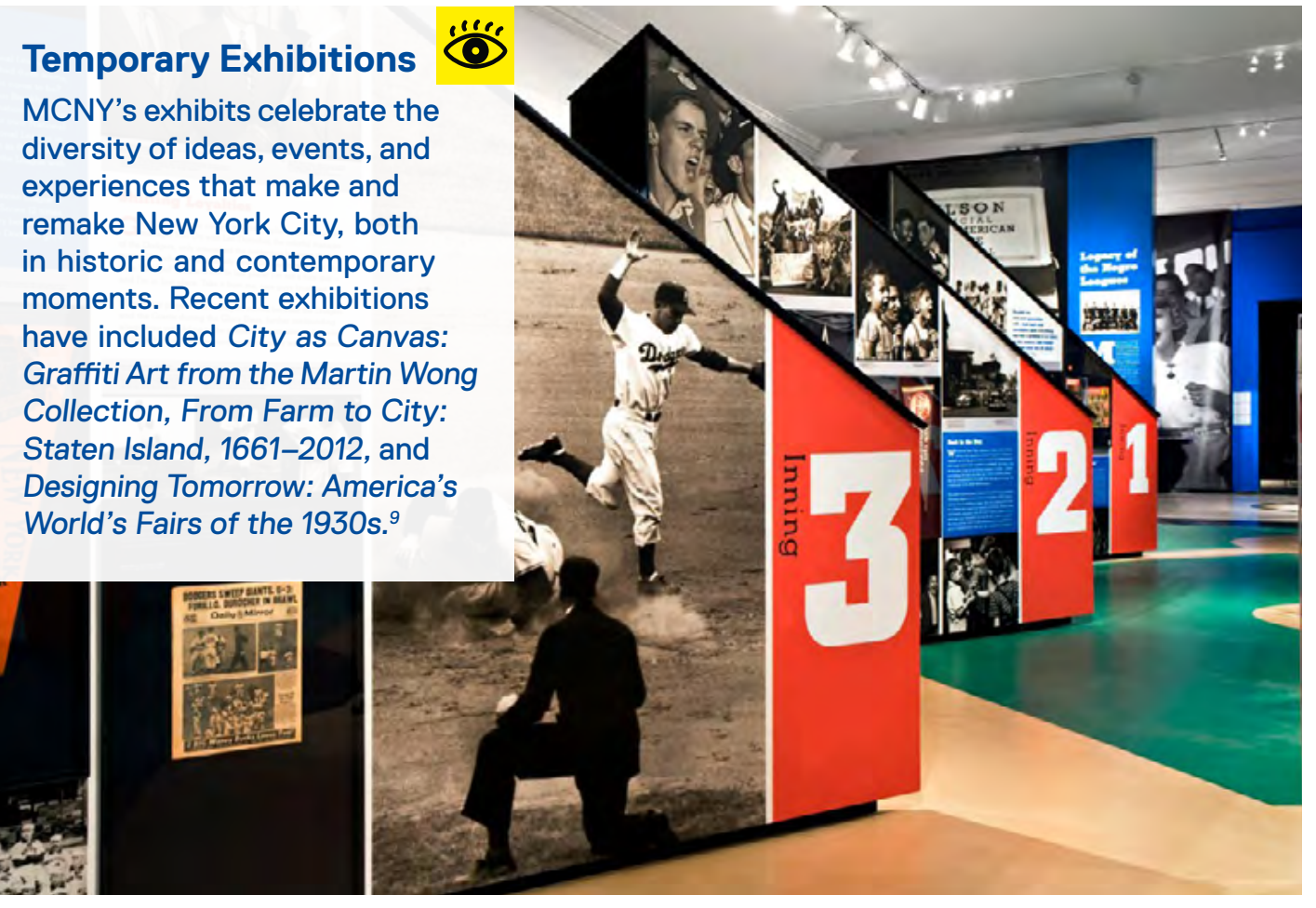

\section{Neighbourhood Programs}

In a testament to its commitment to fostering community, the Museum offers free admission to neighbourhood residents through its "I'm a Neighbour" program. The Museum also hosts Uptown Bounce, a summer block party series that includes music and dancing, gallery talks and tours, and local food. ${ }^{10}$

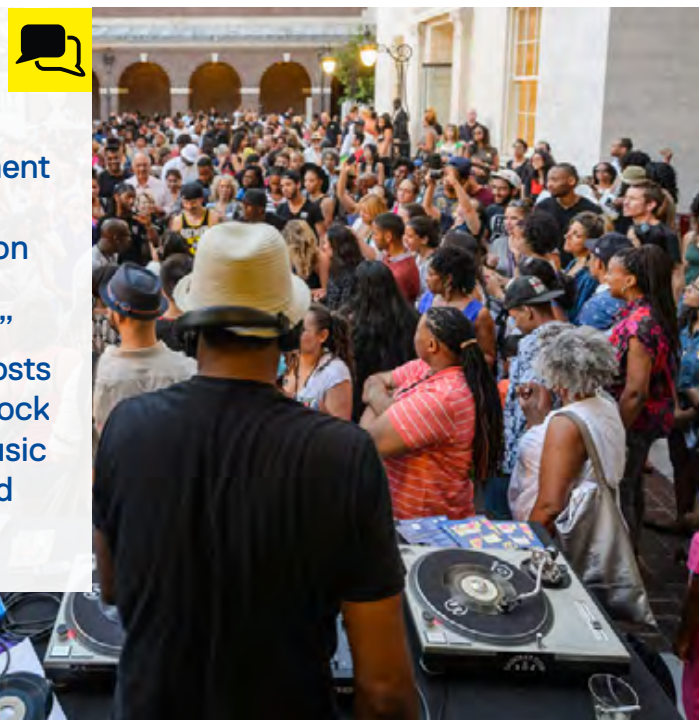

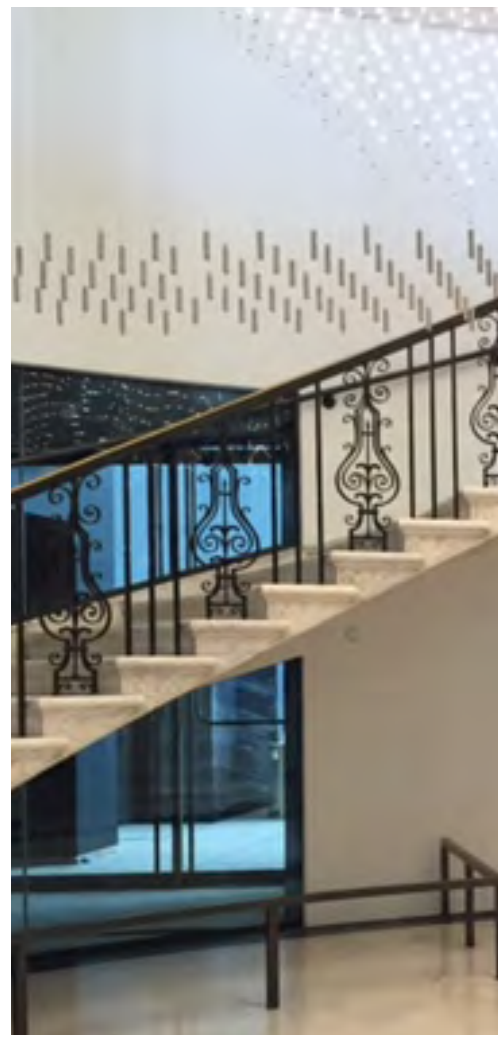

Public Programming

Programs often include walking tours, films, panel discussions, and live performances. The 2013 exhibition Making Room: Models for Housing New Yorkers, included a panel discussion, design competition, and immersive displays. The exhibit explored the challenges of providing New Yorkers with dignified microapartments in an increasingly constrained housing market. 
Frederick A.O.

Schwarz Children's

Center

Serving nearly 50,000 students annually, the Children's Centre draws on the Museum's rich collections to create a learning experience that allows local youth to connect their personal experiences with the greater narrative of the city's evolution.

\section{Special Events}

The MCNY hosts public forums and debates on city history as well as current issues affecting New Yorkers such as housing, cycling, and urban arts and culture. Working with local organizations already engaged in the issues explored in the Museum's exhibits, the MCNY ties its programming with the city to deeply engage visitors.

\section{LESSONS FOR OLD CITY HALL}

The MCNY is unique among other civic museums for its ongoing community efforts and its engaging approach to programming that is integrated with the broader context of the city.

New Yorkers have sought to preserve and promote their collective identity through the MCNY since the late 1920s. While the Museum's artifacts and objects represent a physical legacy of shared history, its most significant impact today comes from its events and programming. The MCNY's public events and interactive programs bring the past to life and respond to present issues, building upon the archival collections, bridging the gaps between then and now, and stitching together the multitude of urban experiences.

The MCNY's phased approach to its building modernization efforts has allowed it to remain open and operational throughout its redesign. By implementing temporary iterations of elements that will be permanently included later in the process, the Museum allows visitors to engage with the actual process of its evolution, letting users get a feel for what is to come while creating a positive experience during the construction phase. 


\section{Canadian Centre for Architecture}

With research

facilities, archives, museum galleries, and public programs, the Canadian Centre for Architecture improves public understanding of the role of architecture and urbanism in contemporary society.

\begin{tabular}{|c|c|}
\hline 79 & $00+$ \\
\hline $\begin{array}{l}\text { CCA founded } \\
\text { by Phyllis } \\
\text { Lambert }\end{array}$ & $\begin{array}{l}\text { Researchers and } \\
\text { scholars hosted } \\
\text { through Visiting } \\
\text { Scholar and }\end{array}$ \\
\hline $\begin{array}{l}1989 \\
\text { CCA opens }\end{array}$ & $\begin{array}{l}\text { Support Grant } \\
\text { programs }\end{array}$ \\
\hline $\begin{array}{l}130,000 \text { sq. ft. } \\
\text { Area of new } \\
\text { building addi- } \\
\text { tion (approxi- }\end{array}$ & $\begin{array}{l}400,000+ \\
\text { Prints, drawings, } \\
\text { photographs, and } \\
\text { publications in the } \\
\text { archive }^{11}\end{array}$ \\
\hline
\end{tabular}

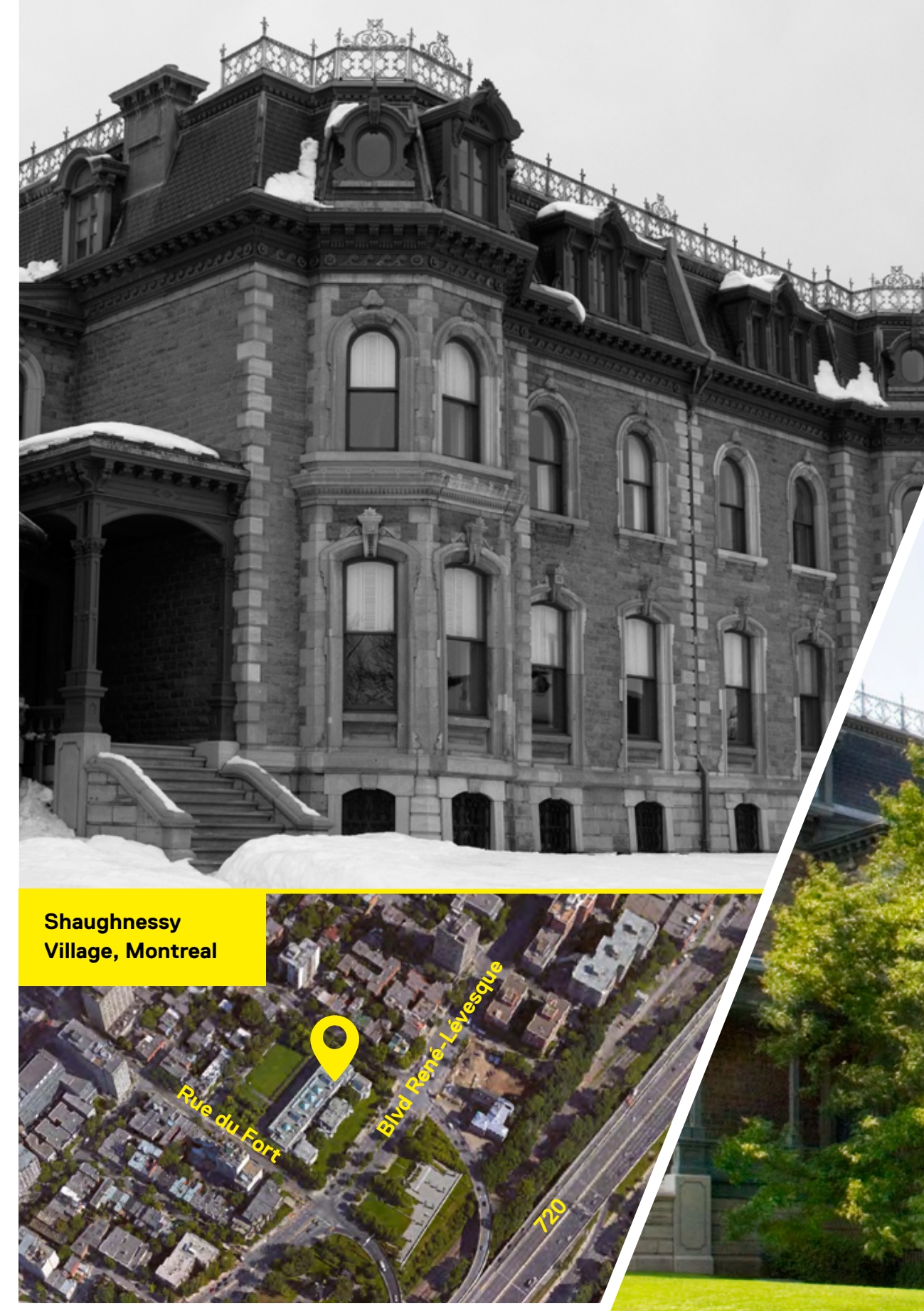




\section{Operating Structure}

The CCA is a non-profit organization governed by an independent board of directors. ${ }^{14}$

\section{Financial Structure}

The CCA is financed by sponsorships from Hydro Quebec, the Bronfman Family, as well as other philanthropic donations from annual partners and donors.

As a research facility, the CCA has strong relationships with other Montreal academic institutions and its archives and collections are an invaluable scholarly resource. While study rooms are free to students and archive access can be arranged by appointment, the CCA does charge a general fee for museum entrance. Access to special events and exhibit openings is often granted for a nominal charge, and students can access exhibits free of charge.

\section{Vernissage}

Public vernissage (pre-opening) events celebrate new exhibitions, installations, and project completions. By inviting the public to participate in lectures and discussion with artists, curators, and academics in a casual environment, these events allow for deeper engagement than conventional museum exhibits.

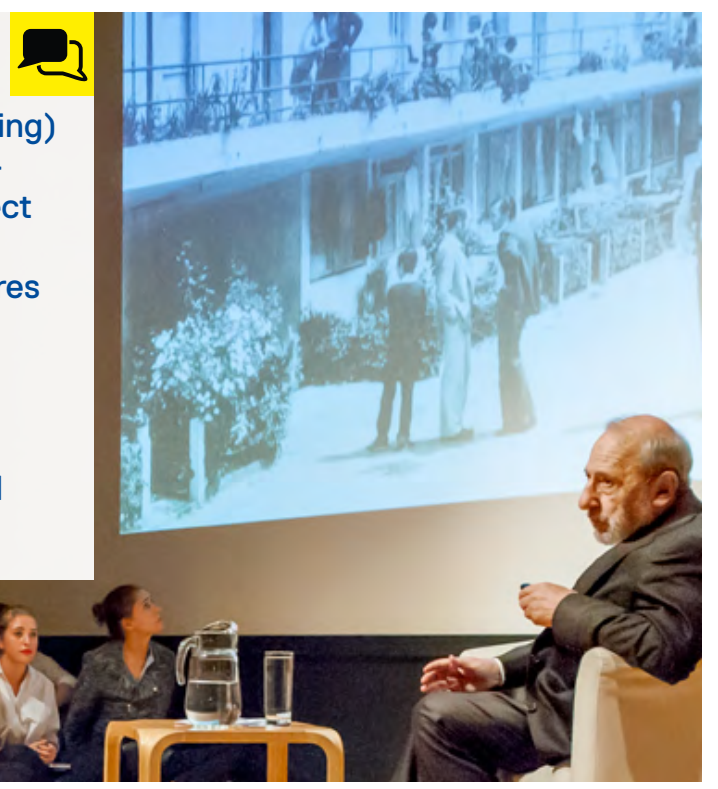

\section{Exhibitions and Publications}

The CCA's exhibitions explore the diversity of ways our lives are shaped by architecture. Rooms You May Have Missed evaluated personal, intimate spaces, and the architectural significance of the private realm on our daily habits.

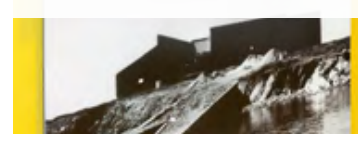

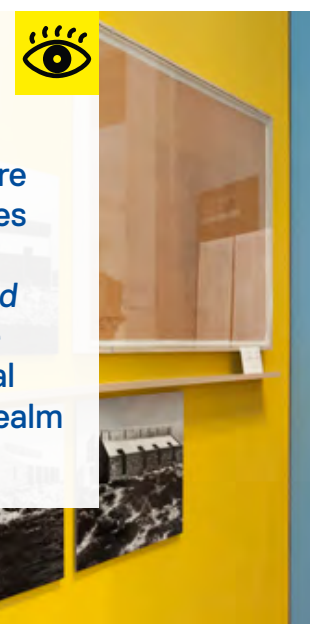

\section{Research and Archives \\ The CCA maintains an interna- tionally acclaimed archival collection of original architectur- al works, sketches, and reports. Its Visiting Scholars Program allows students and academics to pursue research supported by the CCA's extensive collection of resources and materials.}

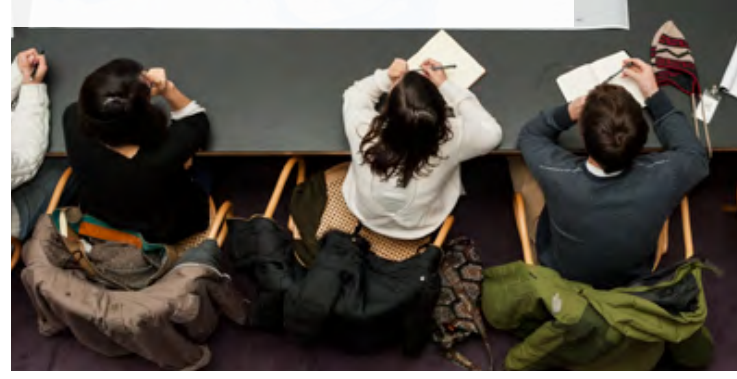

\section{Bookstore}

Owned and operated by the CCA, the store includes in-house exhibition publications as well as books on contemporary architectural practice, history, theory, city planning, photography, museum studies, and design.

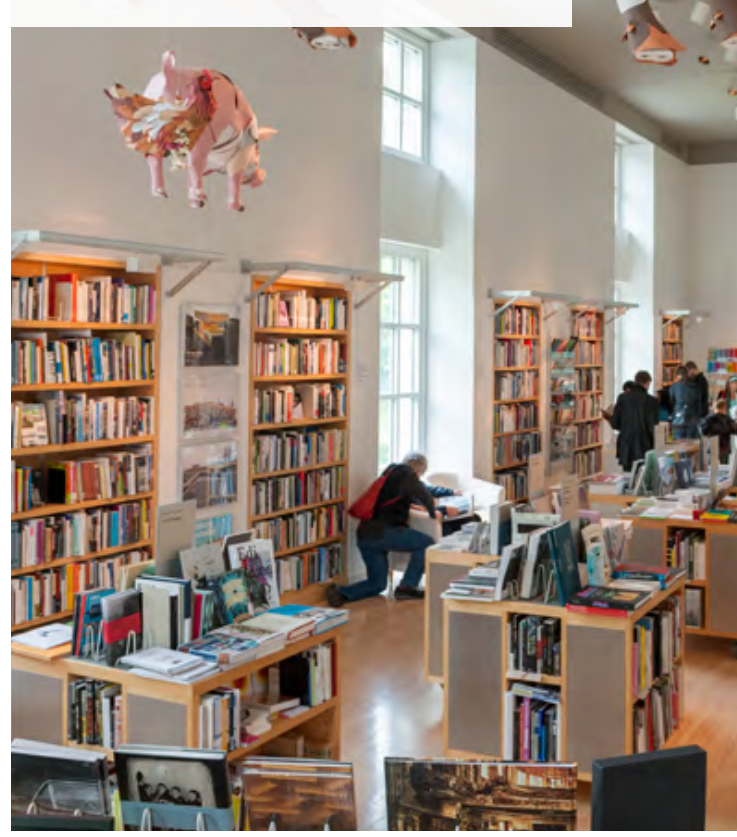



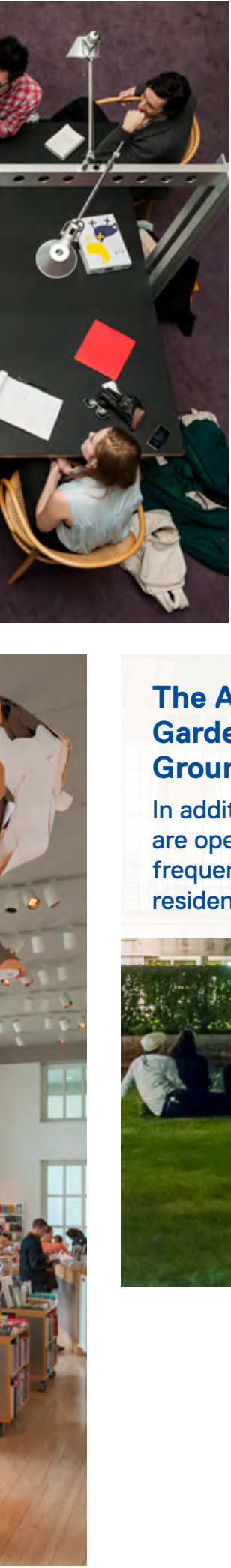

\section{LESSONS FOR OLD CITY HALL}

"We're not a museum that puts things out and says, 'This is architecture.' We try to make people think." -Phyllis Lambert

More than an archive, the CCA is an engaging and provocative space for discourse and conversation that inspires visitors to grapple with the issues of contemporary architecture and urbanism. The CCA combines over 130,000 square feet of museum space, a modern research facility, and an archive of over 100,000 architectural documents. ${ }^{15}$ The CCA holds engaging monthly events that often incorporate audio/ visual installations, public debates, wine tasting, and dancing. These events allow the archives to become a living, breathing celebration of the city, fuelling learning and dialogue by advancing ideas in a convivial setting.

The CCA has also been credited with helping to revive the surrounding neighbourhood ${ }^{16}$ In addition to drawing museum visitors to the area, the CCA's programming and public spaces have been credited with enhancing public perception of the neighbourhood. 


\section{Berlin Senate \\ Department for Urban Development and}

the Env

The space housing the City of Berlin's planning department also contains an exhibit of city models that invites the public into the urban development process.

\section{History}

The Senate Department for Urban Development and the Environment is a government body that manages the planning and development of Berlin. The Department is responsible for functions such as city planning, housing, traffic, environmental protection, and historic preservation. In addition to its policy, planning, and administrative

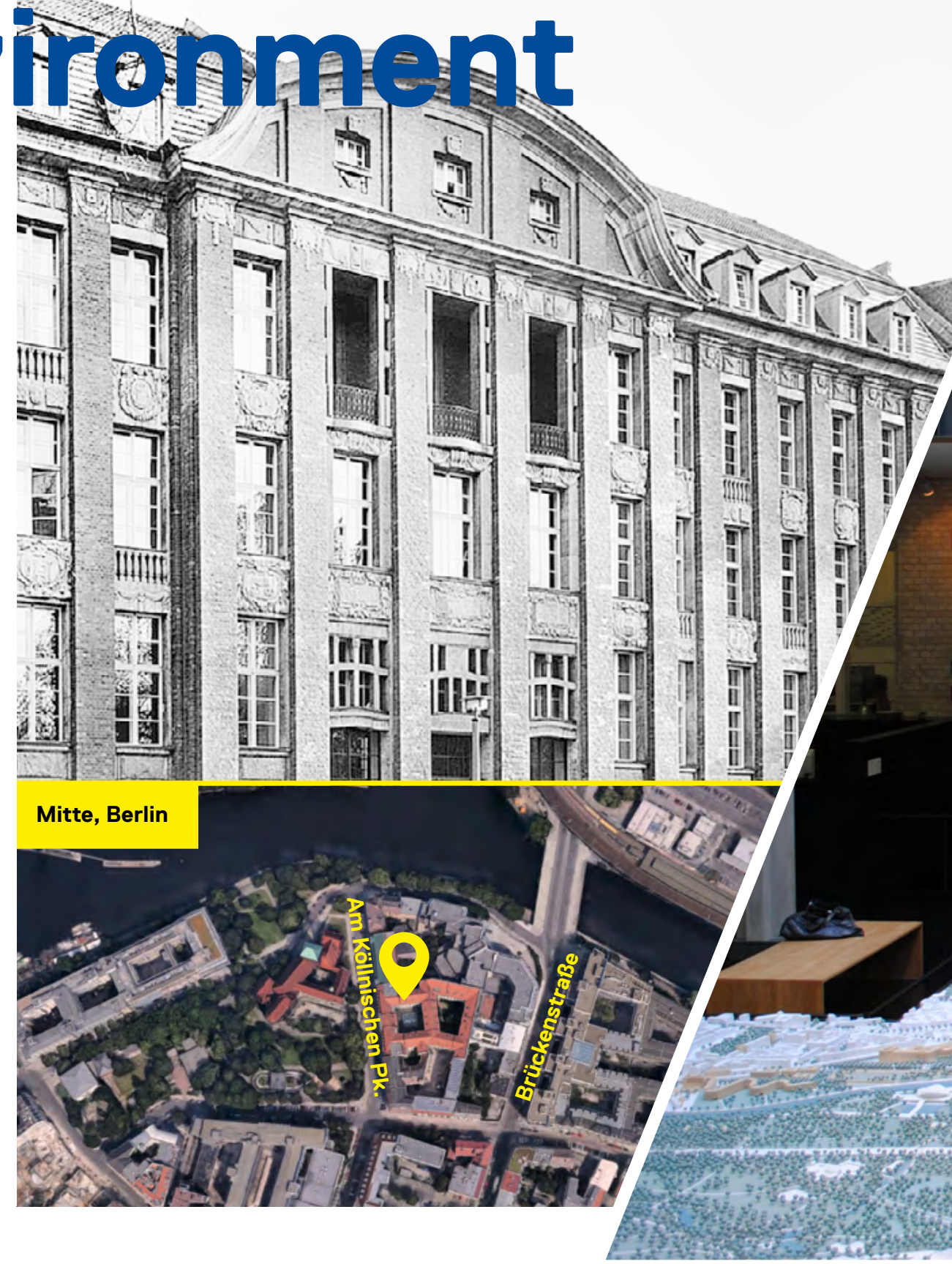


functions, the Department coordinates a permanent exhibition of Berlin city models to educate the public on the city's historic and future development. ${ }^{17}$
Berlin's urban form is the result of top-down master planning and informal adaptations in the wake of post-WWII division and subsequent reunification. ${ }^{18}$ Berlin's pre- and post-reunification periods of design and city building are particularly interesting, and are explored through the Department's models.

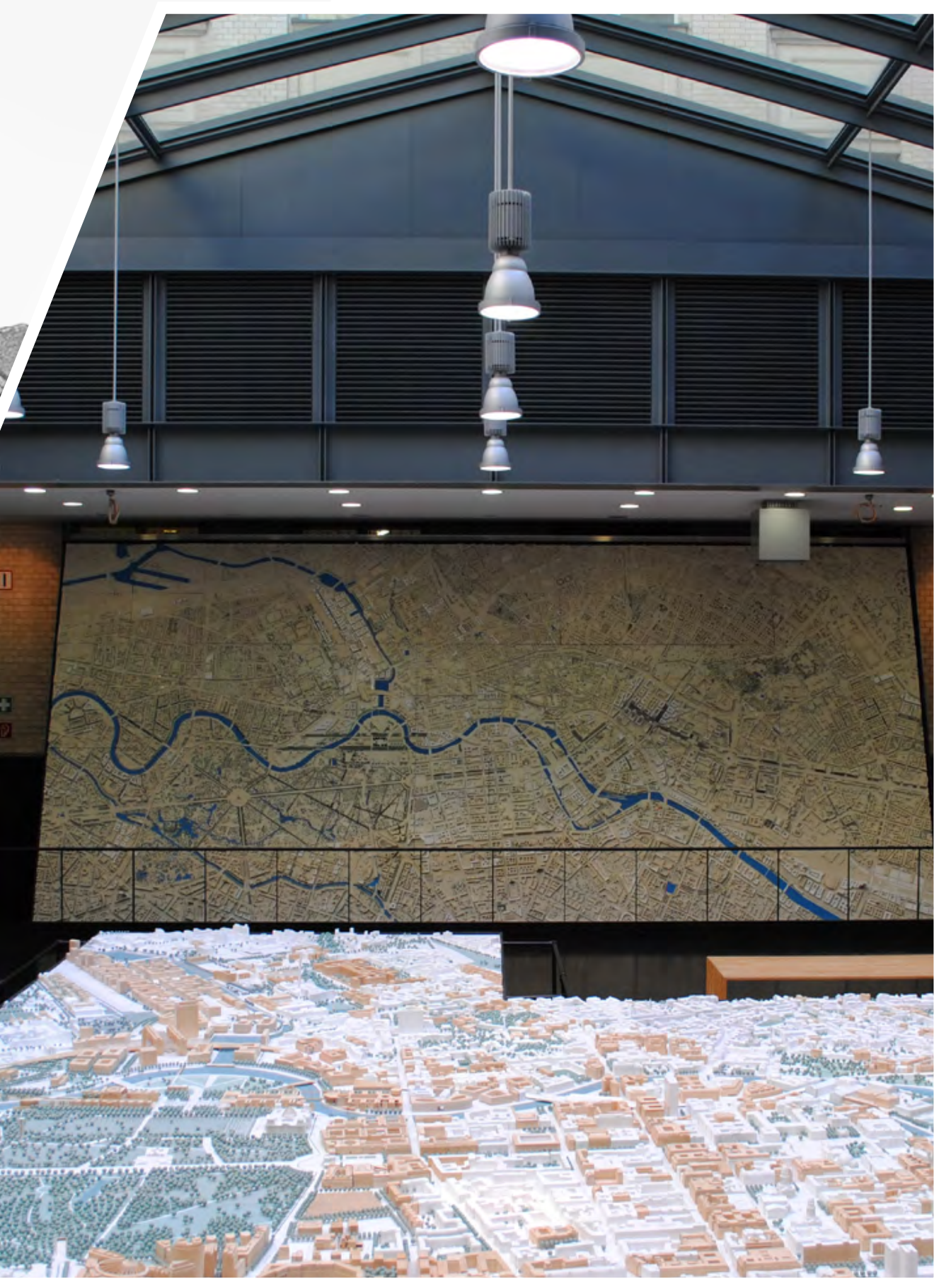

\section{Redesign}

The ground-floor atrium of the Department's 1904 heritage office building in Berlin's Mitte neighbourhood is open daily to the public and features a large exhibition space as well as a smaller area for temporary displays.

The permanent exhibition, "Urban Development - Plans, Models, Projects", includes several large models depicting the urban landscape and built form of the city in different time periods and at different scales. ${ }^{19}$ The models offer visitors insight into the history of Berlin's urban planning and development, as well as a unique understanding of the city's recent growth and evolution.

The Department also manages publicly accessible $2 \mathrm{D}$ and $3 \mathrm{D}$ digital models depicting the current built form as well as future plans. The data is made available for the public to download to allow for informed discussion of various planning scenarios. ${ }^{20}$

1904
Building
constructed
4
City models
in the exhibit
150
Points of
interest on
the Talking
City Model

1904

800

In depth development project profiles, accessible through the Digital Berlin Building Atlas for the "Historic Centre" City Model 


\section{Operating Structure}

Berlin is the capital of Germany, a state in itself as well as the largest city in the country. The Senate Department for Urban Development and the Environment is a publicly-funded branch of the government of the city state of Berlin, and operates as part of the local municipal/state government. The Department contributes to many areas of the city's development, including city planning and culture, housing, mobility, environment and climate, and heritage conservation. ${ }^{21}$

\section{Financial Structure}

As the Senate Department for Urban Development and the Environment is a publiclyfunded government branch, visitors are invited to explore the City Models of Berlin exhibition free of charge.

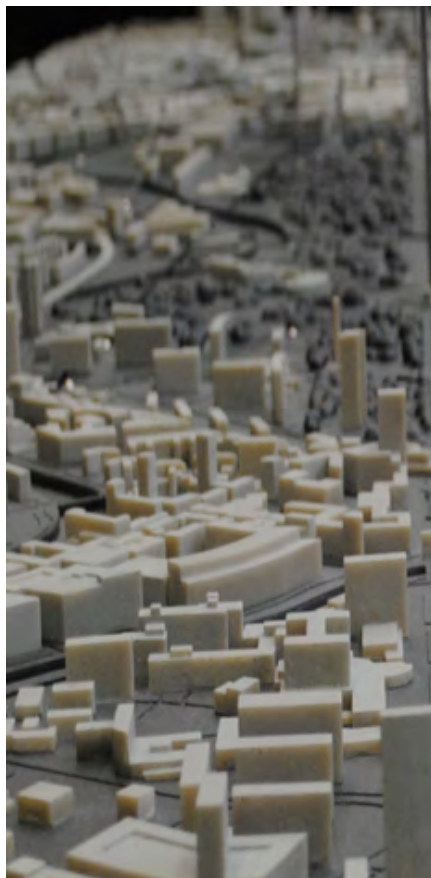

\section{"Historic Centre" City Model}

The city centre is shown in detail at a 1:500 scale depicting pre1990 buildings, contemporary structures, and proposed projects. The model also shows the extensive construction in downtown Berlin since reunification in 1990 , and is continuously updated to reflect new developments. ${ }^{22}$
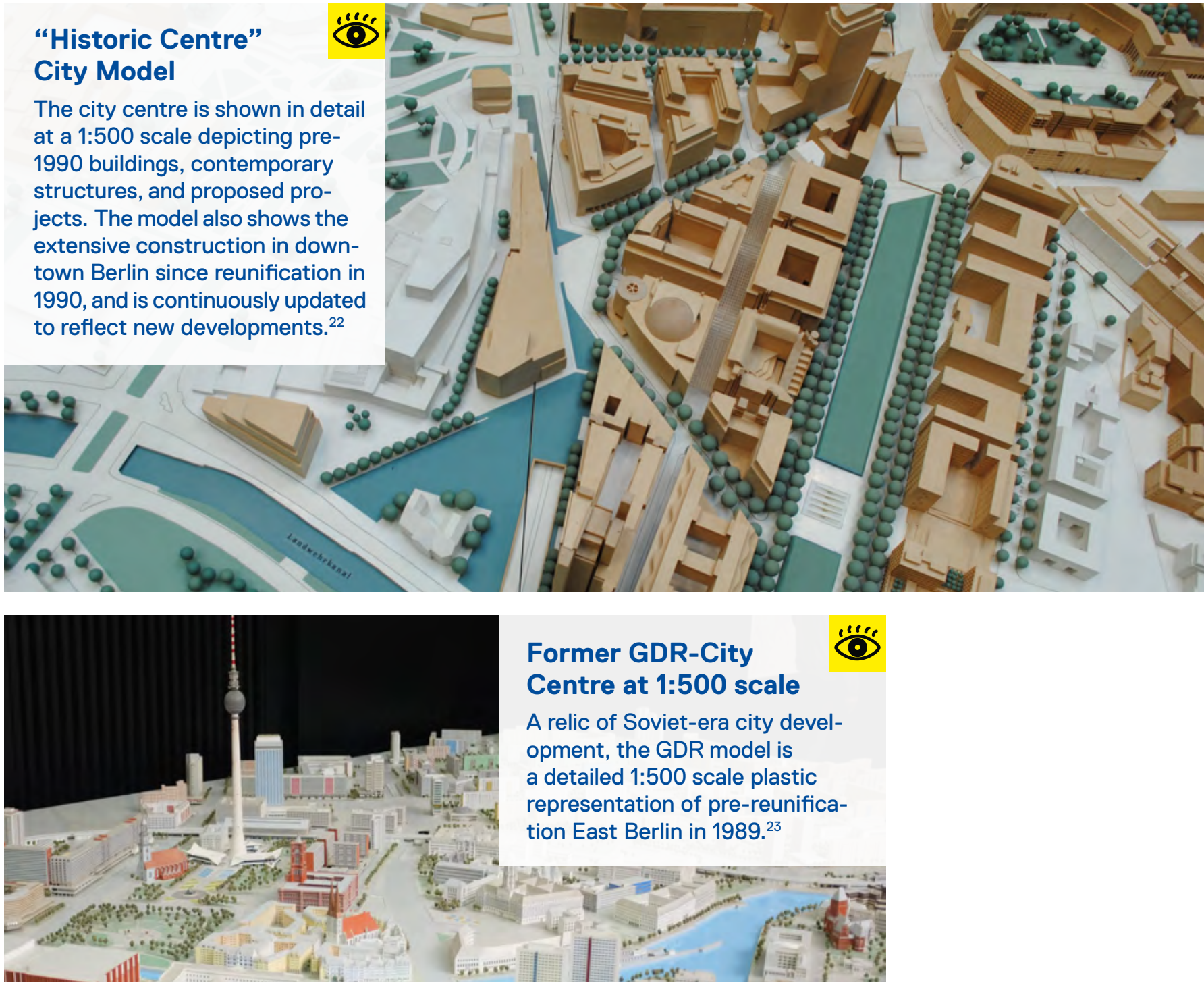
Talking City Model

In keeping with the city's

commitment to accessibility and itsmotto, "Berlin — understandable for everyone", the tactile city model allows the visually impaired to understand Berlin's planning and development through touch and audio aids. ${ }^{24}$

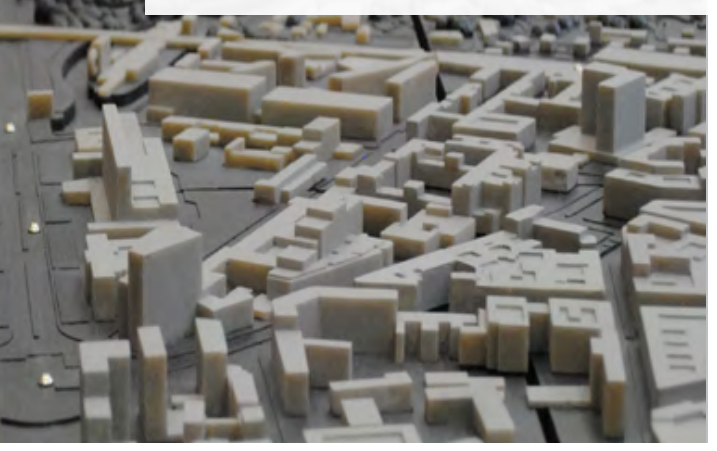

\section{City Model}

At a 1:1000 scale, this model depicts the city centre and its surrounding regions. Various strategic plans are displayed in beige with the existing urban fabric in white. ${ }^{25}$

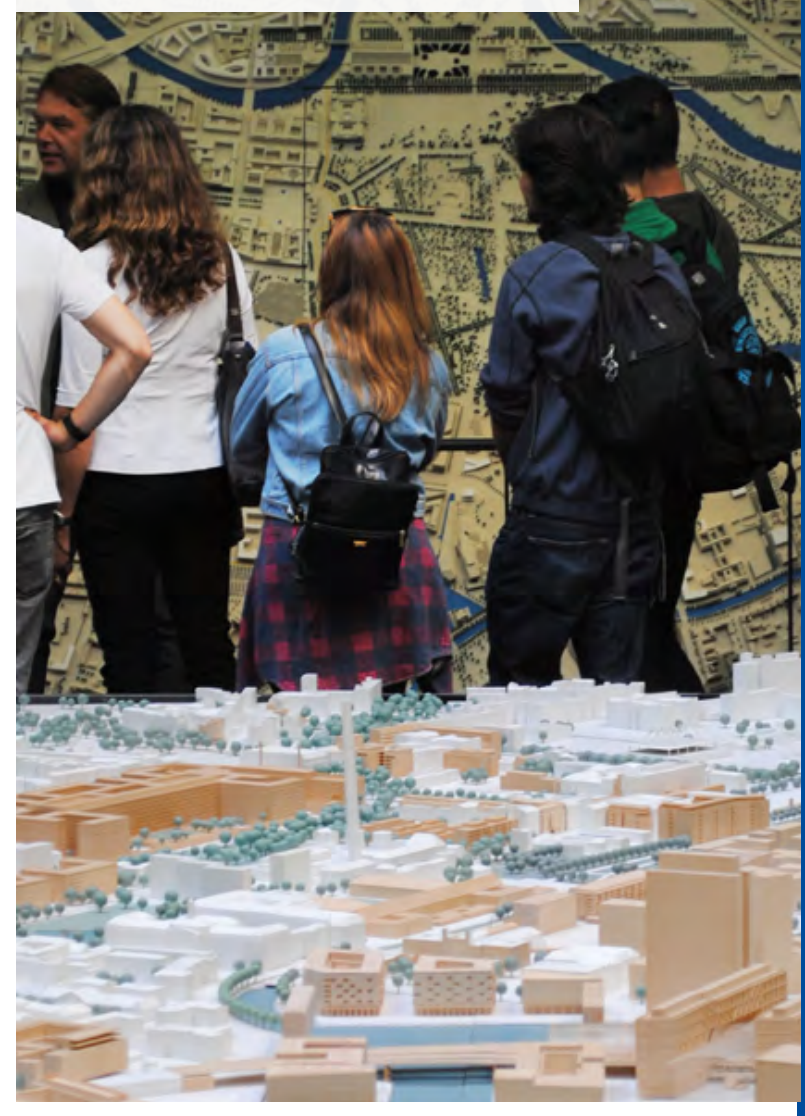

\section{LESSONS FOR OLD CITY HALL}

While the Department's space and exhibits don't fit the mold of a typical museum, the City Models demonstrate the possibilities of pairing government and casual opportunities for public engagement.

By integrating municipal government functions with interactive models and displays, this space encourages people to engage with the city's development from a fresh perspective and scale. For example, the new 3D printed city model is made to be touched, so visitors can gain a new understanding and appreciation of their city.

As a counterpoint to the conventional municipal bureaucracy, the city models offer an approachable opportunity to engage with the implications of land use planning and policy. Admission is free and visitors are welcome to come and see the exhibit Monday to Saturday from 10am-6pm. In addition to the grand exhibition hall, there is also a separate exhibit space for smaller temporary displays that explore other dimensions of development and the environment, such as housing, urban ecology, or transportation. 


\section{Design Exchange}

\section{The Design Exchange is a cultural institution dedicated to design excellence and edu- cation with a special empha- sis on Canada's design heritage.}

1937

Toronto Stock

Exchange

building opens

at 234 Bay

Street

1994

Design Exchange opens in the former Toronto Stock Exchange building

$450+$

Industrial design objects in the collection

$1000+$

Paper archives in the collection

$300+$

Exhibitions mounted ${ }^{26}$

\section{History}

The Design Exchange (DX) is Canada's only museum dedicated to design excellence and heritage. Founded in the 1980 s out of concern over the lack of support for Canadian design, the DX has developed into a cultural design centre with a mandate to collect and preserve the best Canadian materials designed since $1945 .^{27}$

The concept for the DX was shaped through years of community advocacy and support

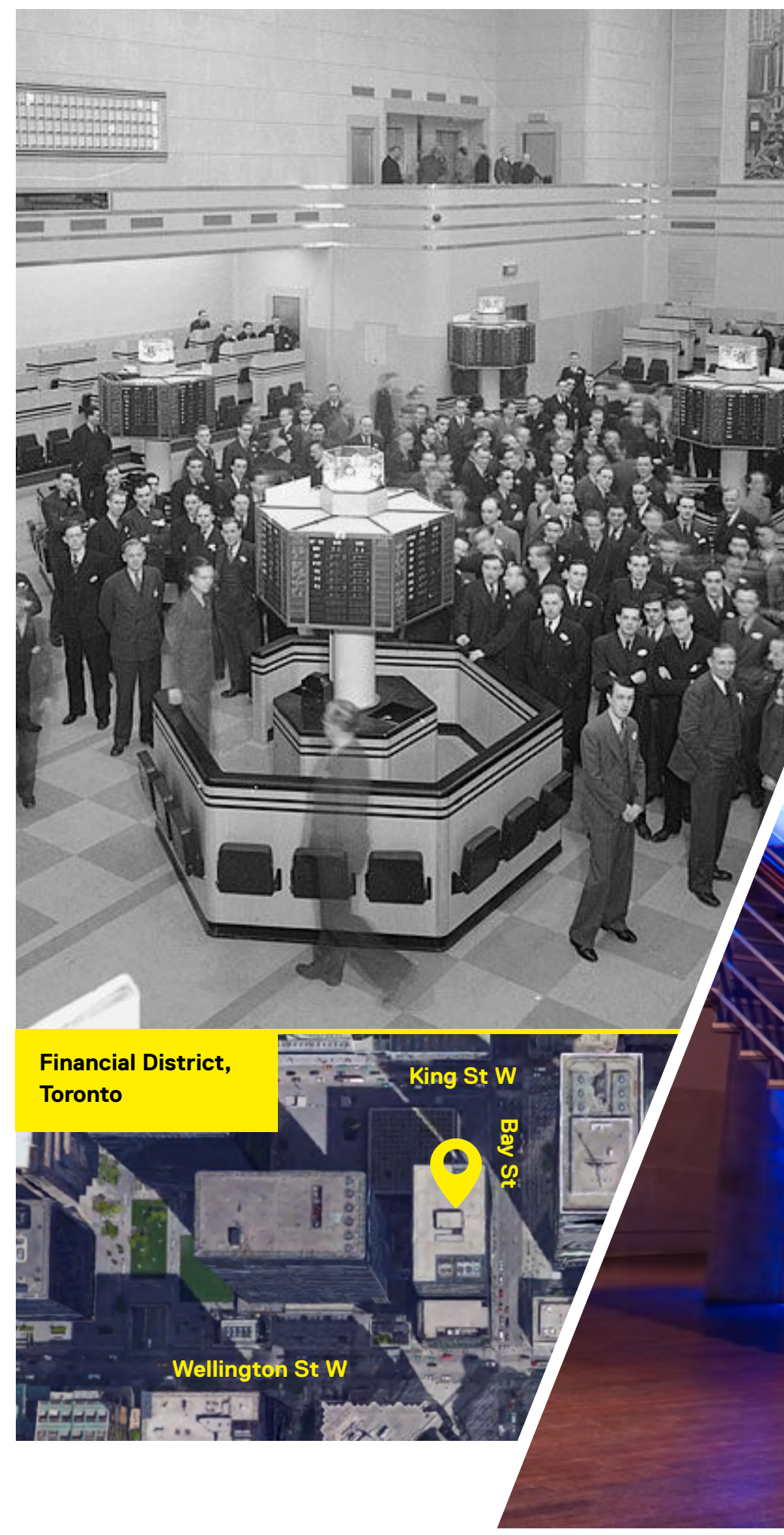




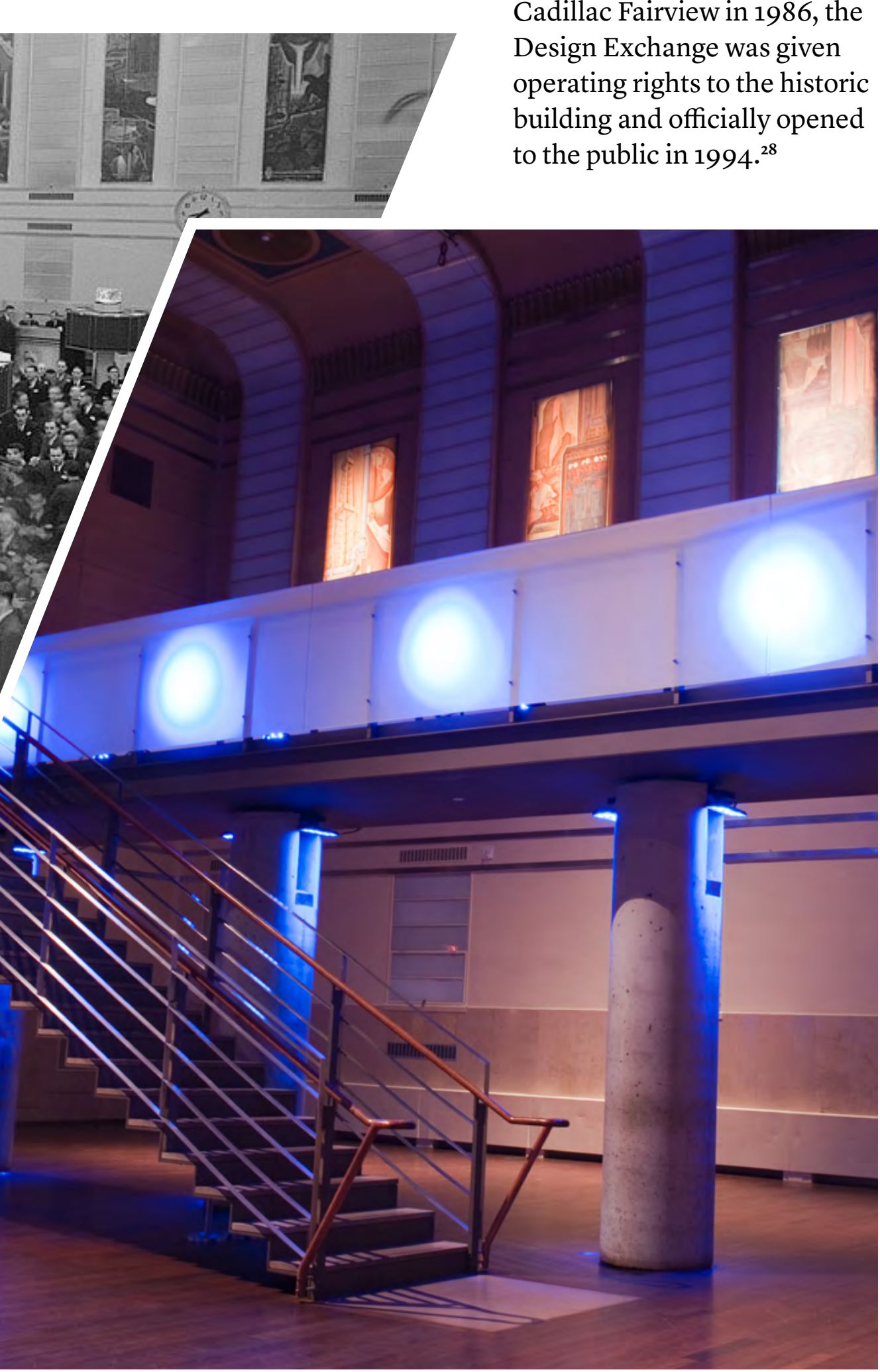

from the design community, eventually transforming into a non-profit organization with a founding board of directors. With the purchase of the old Stock Exchange property by Cadillac Fairview in 1986, the Design Exchange was given operating rights to the historic building and officially opened to the public in $1994 .^{28}$

\section{Redesign}

The building that now houses the DX has gone through many iterations. First opened in 1937 as the home of the Toronto Stock Exchange, it features an art deco facade and a grand trading floor. In 1967, the building was enveloped and incorporated into Mies van der Rohe's modernist Toronto Dominion Centre Towers. In 1986, following the exit of the Stock Exchange and a Toronto City staff report recommending a Toronto design institution for the space, the building was sold to TD Centre developer Cadillac Fairview. The sale required that the heritage building be preserved and the design institution proposal be incorporated into any future project for the site. This founding agreement also secured $\$ 500,000$ annually for 25 years for operations of what would become the Design Exchange. ${ }^{29}$

In 1988, Kuwabara Payne

McKenna Blumberg Architects (KPMB) renovated sections of the DX that weren't designated for historical preservation, transforming the space to include modern exhibition areas, offices, a resource centre, and meeting rooms. Since 1992, the City of Toronto has held a long-term lease for the space of the former Stock Exchange, and in turn, the DX has subleased the space until 2091. ${ }^{30}$ 


\section{Operating Structure}

The DX constitutes a non-profit design museum, educational facility, and event space. It is governed by an independent board of directors that includes two Toronto City Councillors who serve as the City's representatives.

\section{Financial Structure}

The Design Exchange is partially funded through grants and support programs from the City of Toronto and is also funded by revenue generated through events and external programs. The DX originally had a funding agreement with

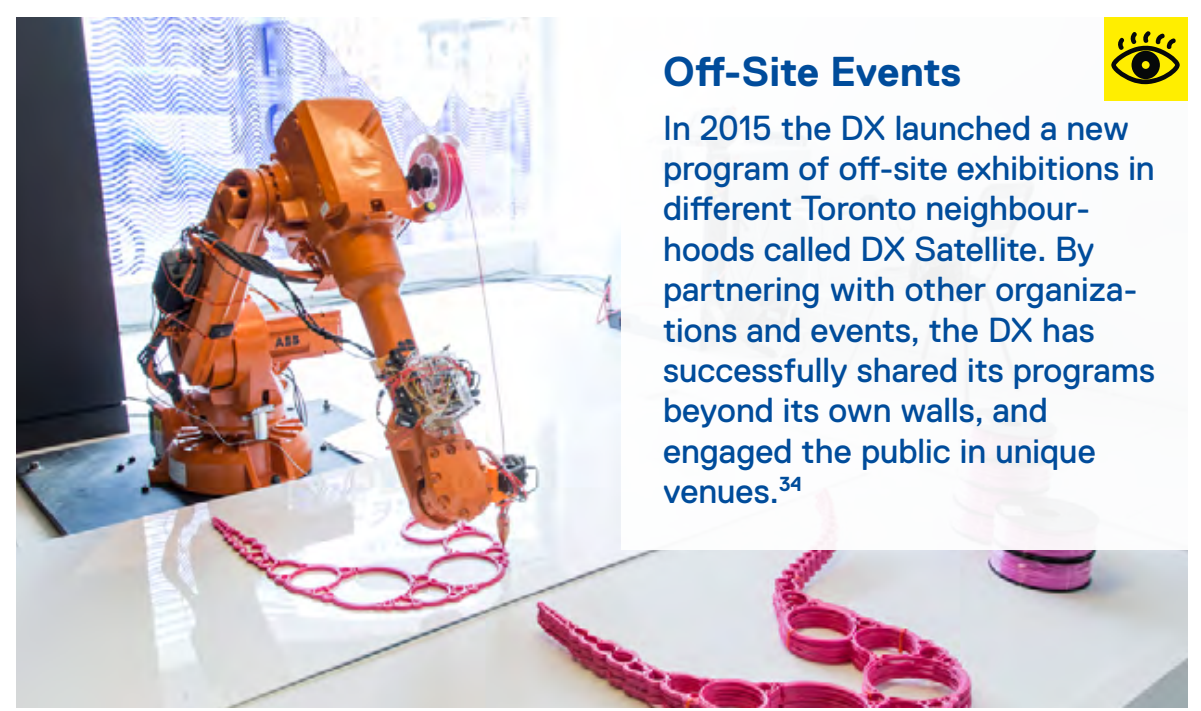

developer Cadillac Fairview to receive $\$ 500,000$ annually for 25 years. But since the grant's expiration in 2013, ${ }^{31}$ it has dedicated substantial resources to re-organizing their operational model in order to achieve financial sustainability. Part of this ongoing strategy has resulted in the Design Exchange's decision to increase the size of the onsite rental space, and focus on off-site public exhibitions through a satellite model. ${ }^{32}$

In April 2015, the City of Toronto's Economic
Development \& Culture Division allocated $\$ 200,000$ to help the DX maintain operations since the end of the 25-year funding agreement with Cadillac Fairview. The City of Toronto is currently negotiating whether this \$200,00o allotment can remain an annual contribution. In the meantime, the DX is focused on sourcing the remaining \$300,000 from the private sector and other levels of government. ${ }^{33}$

\section{Private Events}

Private events such as weddings and conferences are a key element of the DX's operational structure. The DX provides a range of spaces as well as expertise and technical support to facilitate popular events.
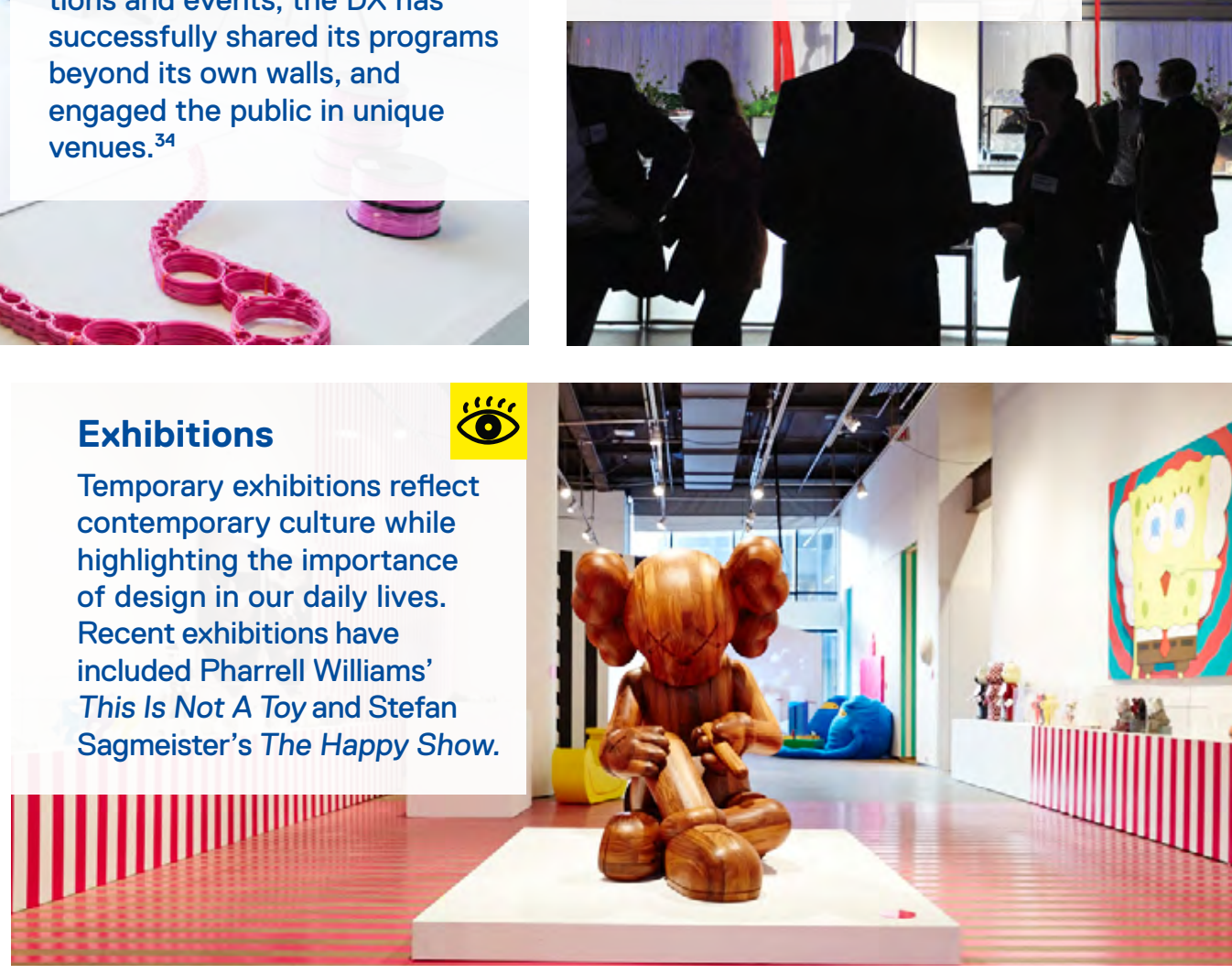
Permanent Collection

The DX's permanent collection highlights the contributions of Canadian designers, innovators, and artisans to industrial design. The collection includes over 600 design objects such as furniture, housewares, textiles, and electronics. ${ }^{35}$

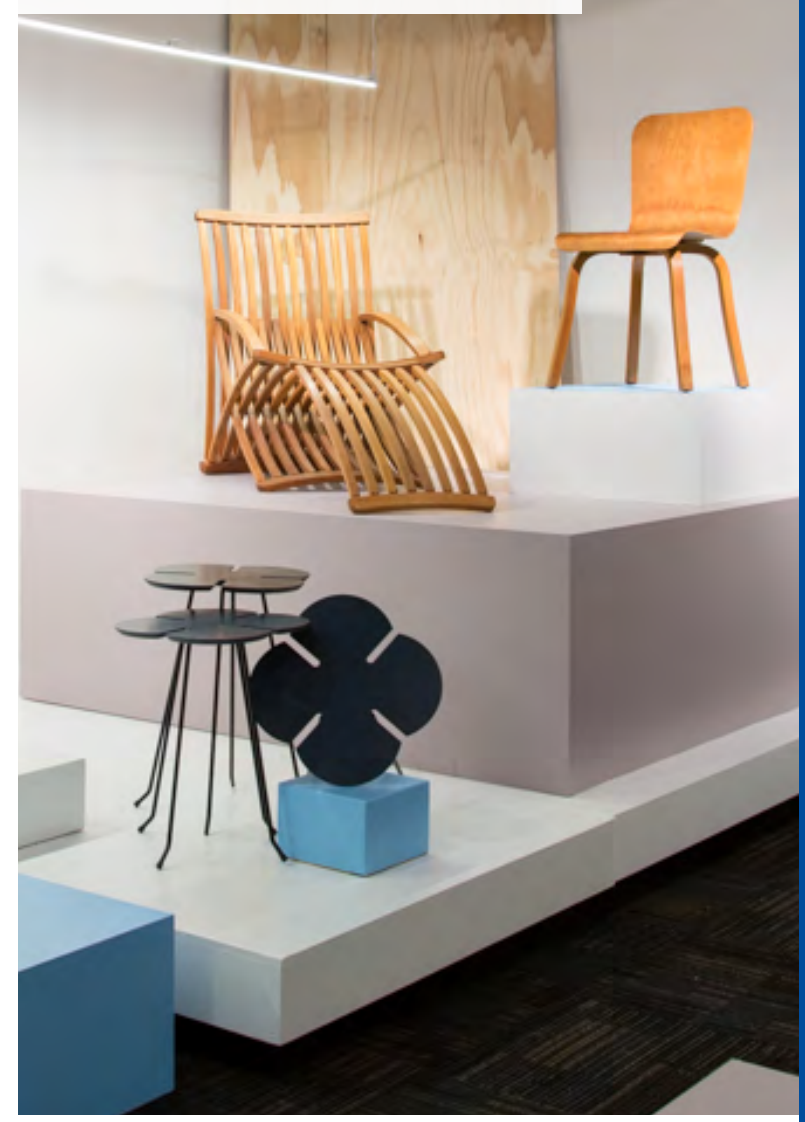

\section{LESSONS FOR OLD CITY HALL}

The Design Exchange's balanced approach to programming, including both private and public events, makes it a unique cultural institution. Its mix of funding streams and opportunities for engagement shape a space and an organization that is relevant and accessible to a range of audiences.

As part of its ongoing strategic review, the DX is exploring different long-term funding opportunities. One potential approach is a satellite model, where the DX would continue to promote and host off-site events and exhibitions to specific Toronto audiences. This approach would allow the main DX facility to remain available for private functions. ${ }^{36}$ Meanwhile, the permanent collection space has been expanded and its exhibits are publicly accessible from Tuesday to Sunday. ${ }^{37}$

The Design Exchange's broad scope incorporates several distinct disciplines, ranging from industrial and interior design to fashion and architecture. Design literacy, which transcends any of these discrete disciplines, is relevant to nuanced understandings of the city and civic experience. 


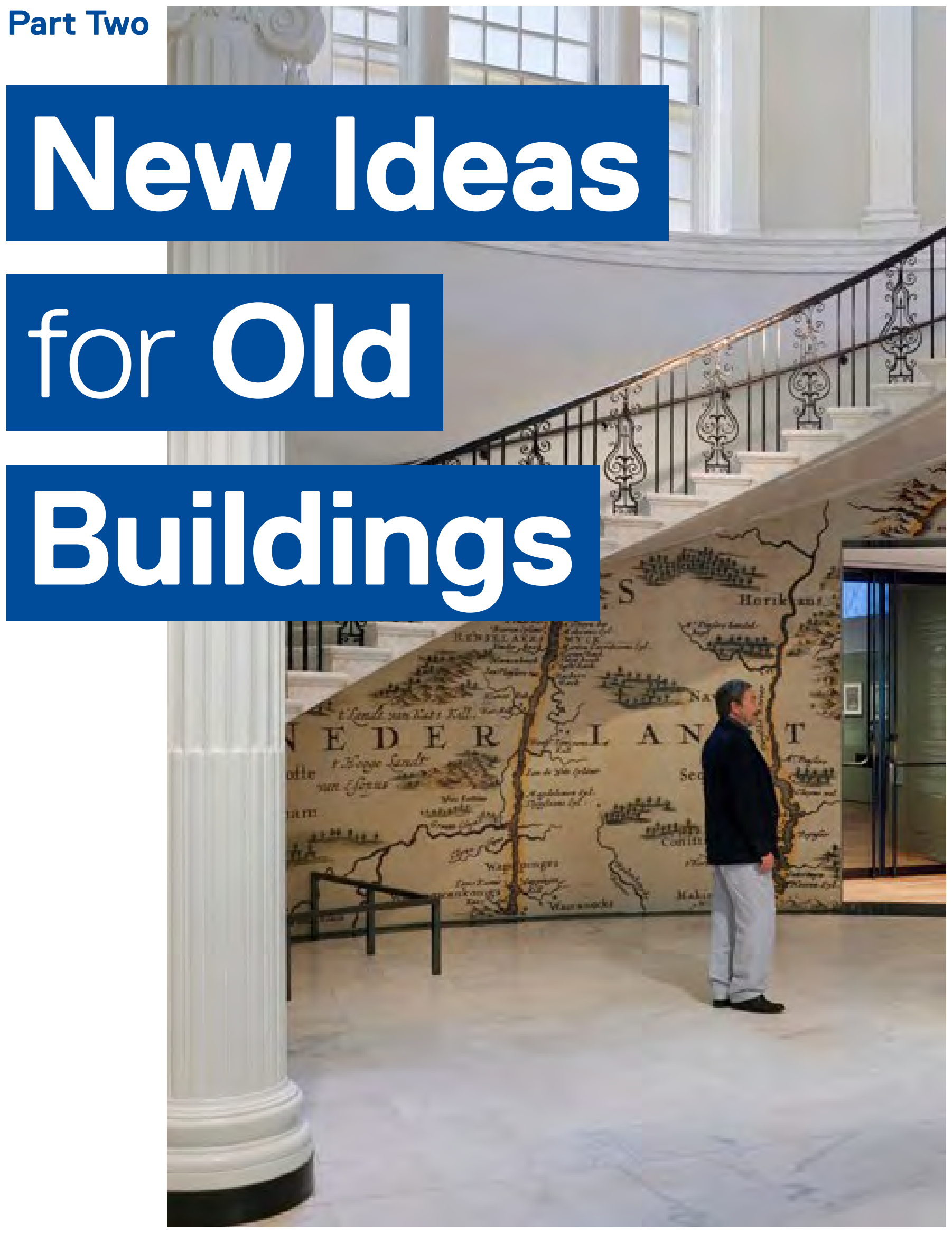

Museum of the City of New York 
Old City Hall's grandeur, historical significance, and central location offer incredible opportunities for renewal. But there are challenges. Its size and historical features are expensive to maintain, while load-bearing interior walls present obstacles to expanding or reconfiguring interior spaces. ${ }^{38}$ While it's important to recognize the structure's unique architectural features, it's equally important to ensure it continues to evolve.

With the anticipated departure of the courts in 2021, Old City Hall is now ready for reinvention. ${ }^{39}$ With the City's criteria that the building maintain public access, incorporate mixed uses, and ensure financial sustainability, Toronto has an unprecedented opportunity to reimagine and redesign this space. ${ }^{40}$

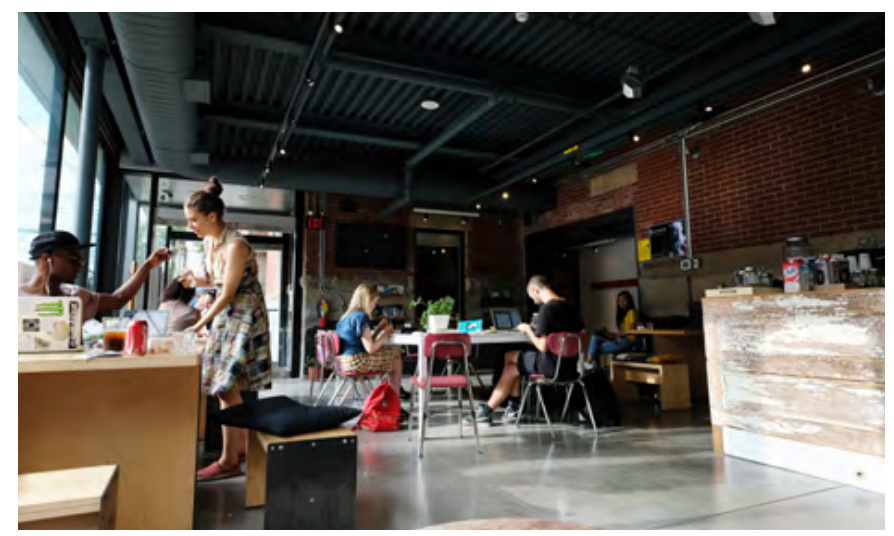


Local

and Global

Examples:

\section{Case Studies}

In Toronto and beyond, architects, heritage professionals, planners, and urban designers are employing creative strategies to repurpose old buildings for new uses. The benefits include heritage preservation, of course, but also environmental sustainability, financial savings, and contributions to a sense of place and local culture..$^{41}$

The following case studies highlight historical structures

that have been thoughtfully adapted for $21^{\text {st }}$ century uses. Cases have been selected for what the buildings were iconic, in the heart of the city, and publicly owned - as well as what they have become dynamic hubs of private and public activity, imbued with a strong identity. How can design strategies creatively incorporate a range of private and civic functions within the building, while inviting the public back in?
One Spadina

Crescent,

Toronto

The Theatre

Centre, Toronto

MoMA PS1, New York City

The Royal Conservatory of Music, Toronto

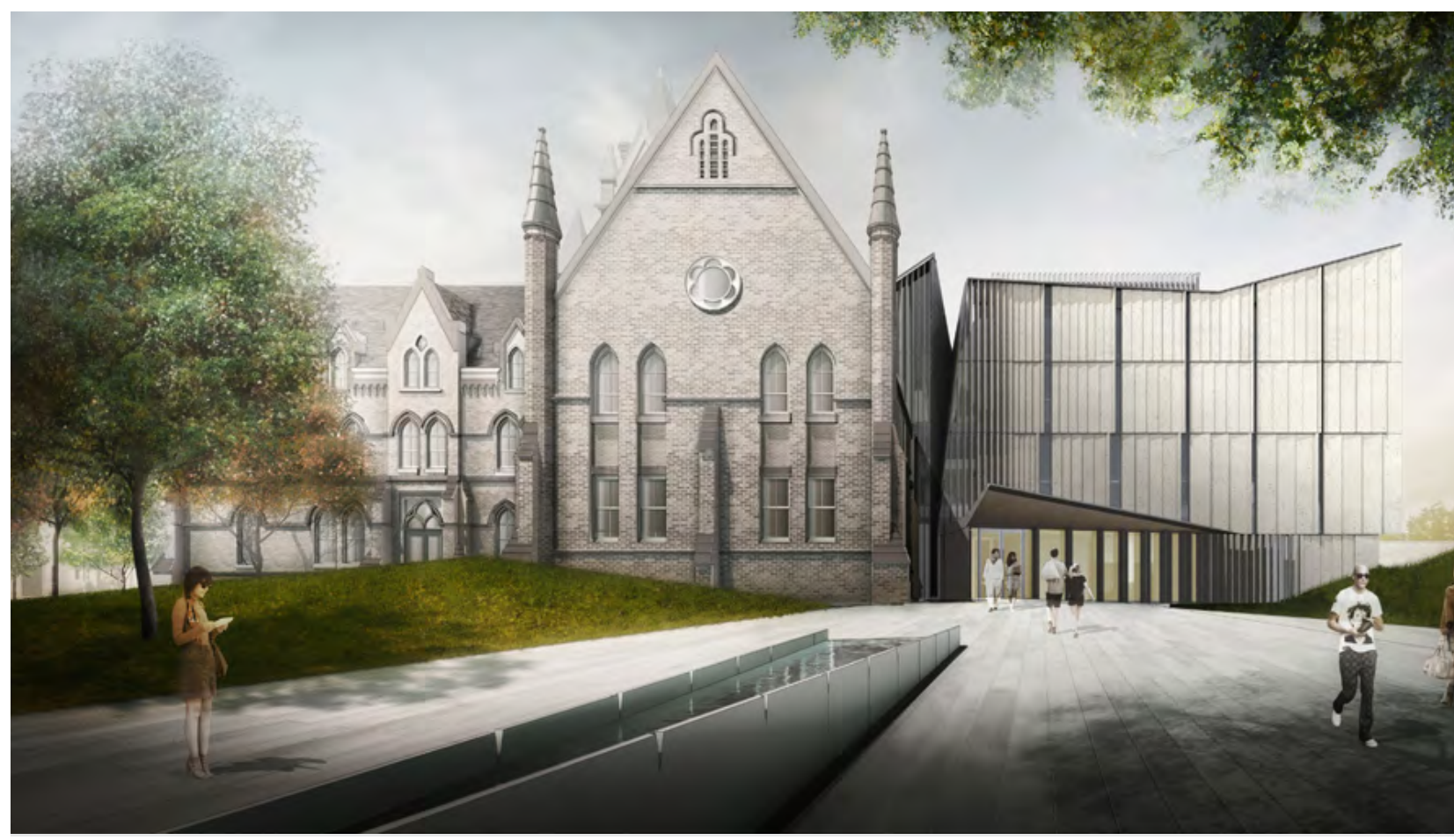




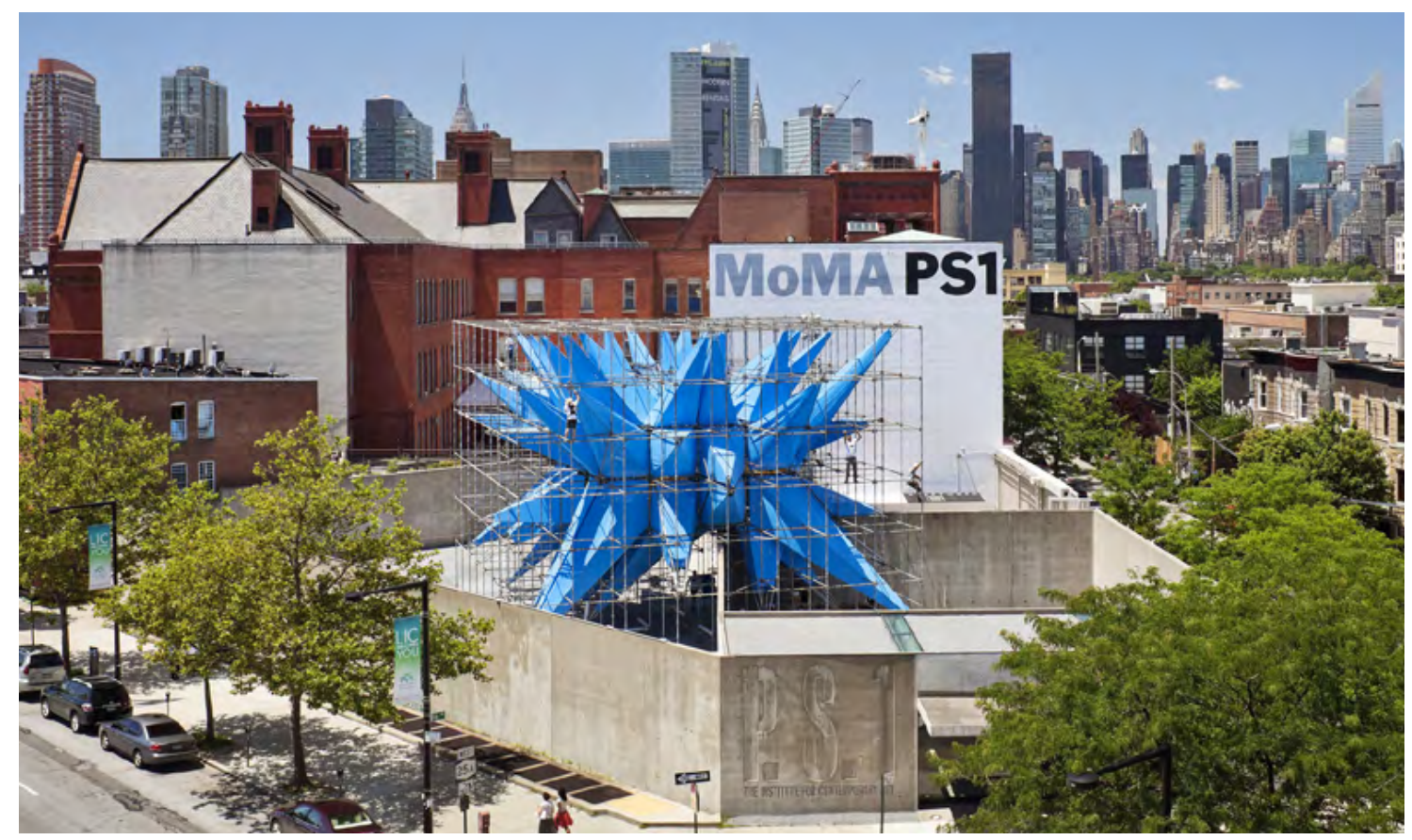

MoMA PS1

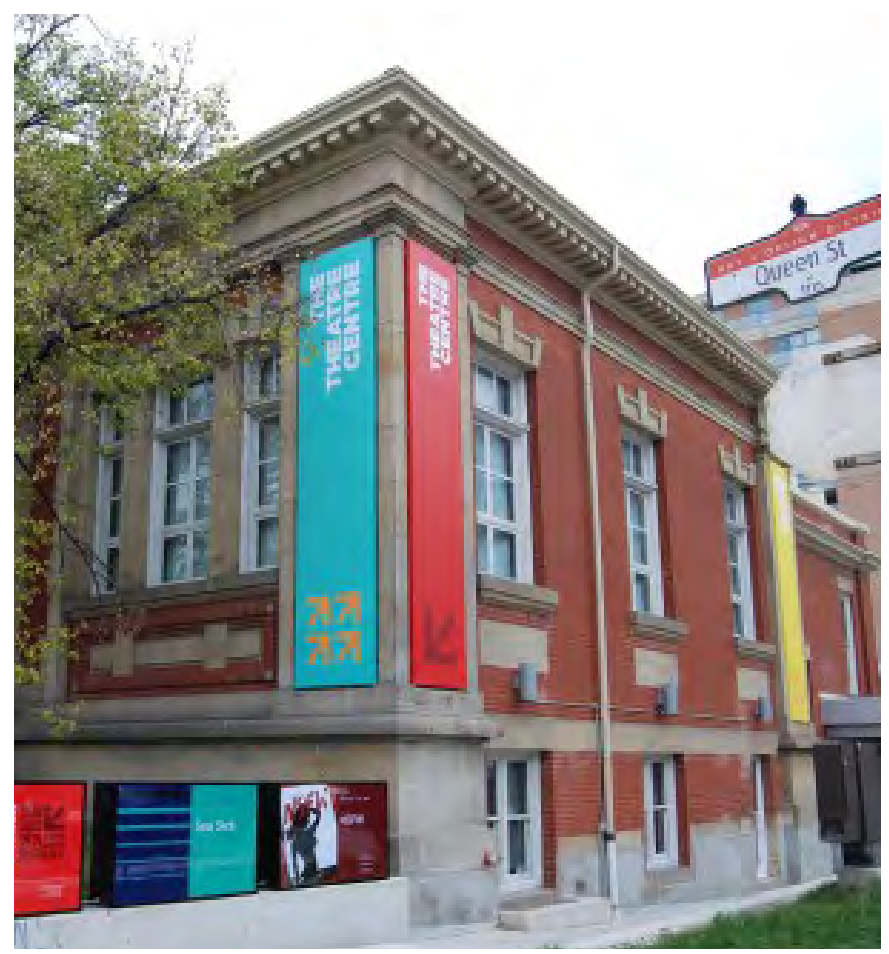

The Theatre Centre

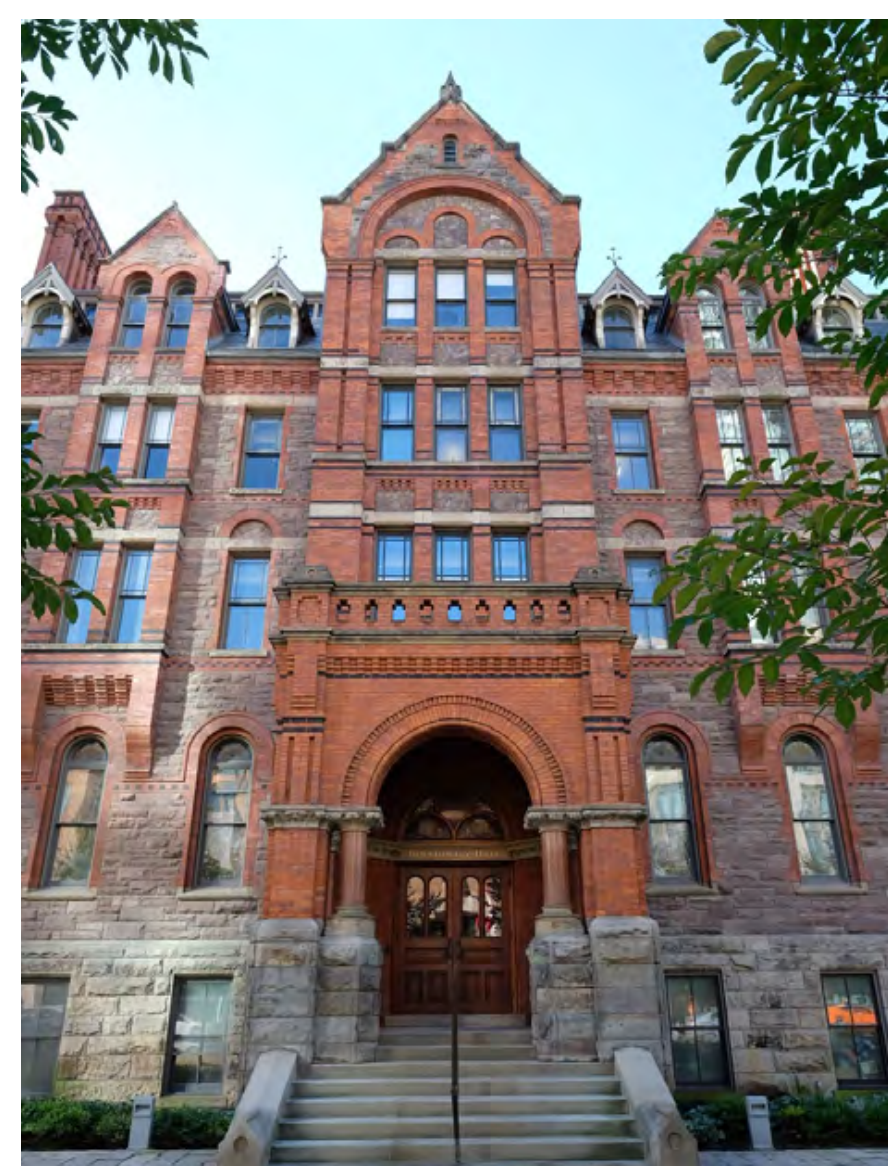

The Royal Conservatory of Music 


\section{Crescent \\ An iconic address on the roundabout of one of Toronto's main north-south arterials, One Spadina Crescent will soon be home to the John $\mathrm{H}$. Daniels Faculty of Architecture,}

One Spadina Landscape and Design.

1875
Original
building
completed
2016
Construction
at One Spadina
set to complete
100,000 sq. $\mathrm{ft}$
Area of building
once renova-
tions are
complete

$\$ 72$ million Total project cost

\$24 million Major donation from John $\mathrm{H}$. and Myrna Daniels ${ }^{42}$
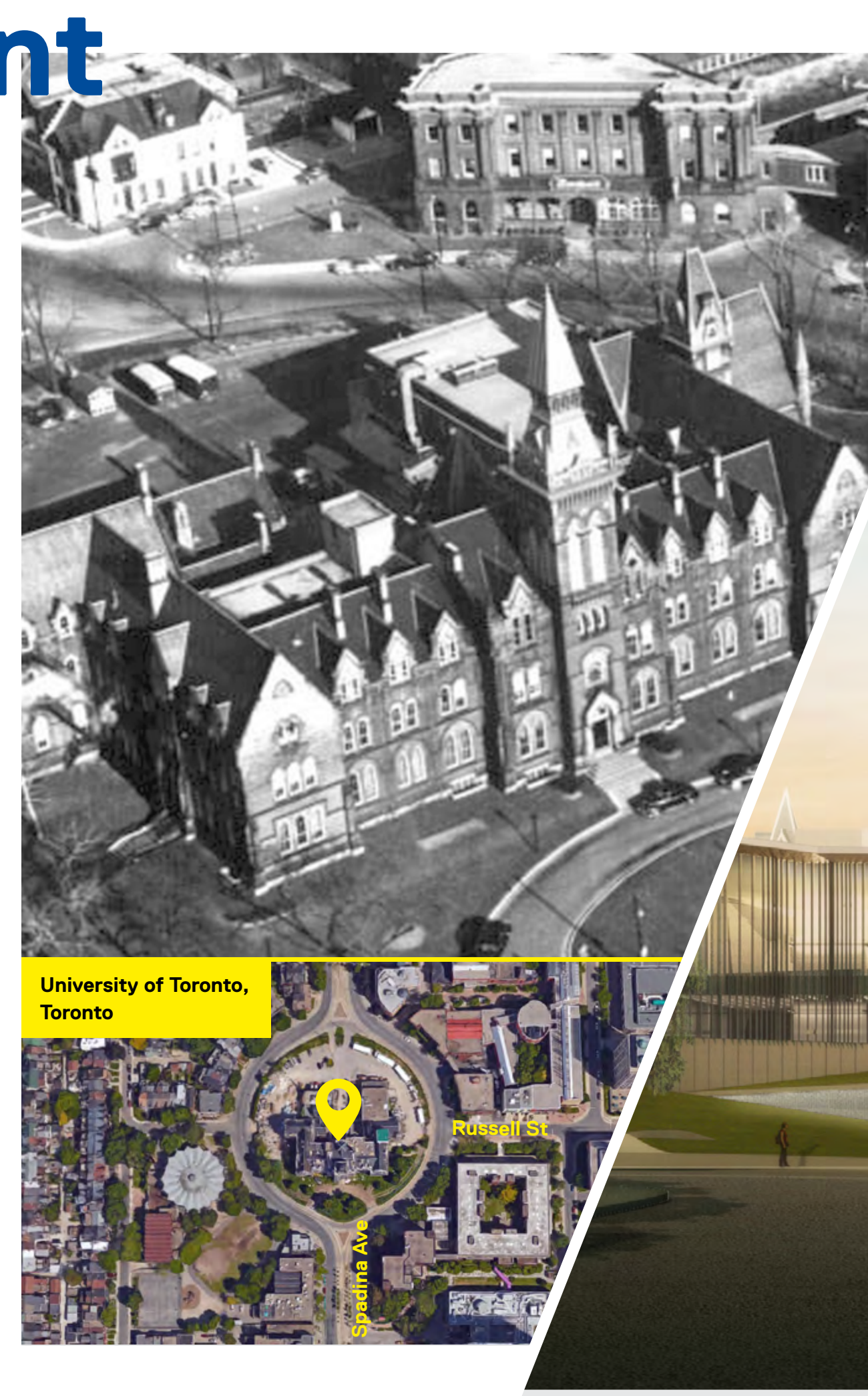


\section{Operating Structure}

While the Faculty of Architecture will bear the name of the Daniels Family, thanks to their generous donation, the University of Toronto will remain the property owner and operator.

\section{Financing Structure}

For the redevelopment, \$24 million of the total $\$ 72$ million cost was contributed by developer and philanthropist John $\mathrm{H}$.
Daniels and his wife Myrna. ${ }^{46}$ The University of Toronto is a public university that derives its funding from government support, student tuition, and private donations. Once renovations are complete, One Spadina will function as the home for U of 'T's Daniels Faculty of Architecture and will be operated, financed, and managed by the University.

\section{Design Studios}

The building will include sprawling open studio space, adaptable classrooms, and exhibition space for architecture, landscape architecture, and urban planning students.

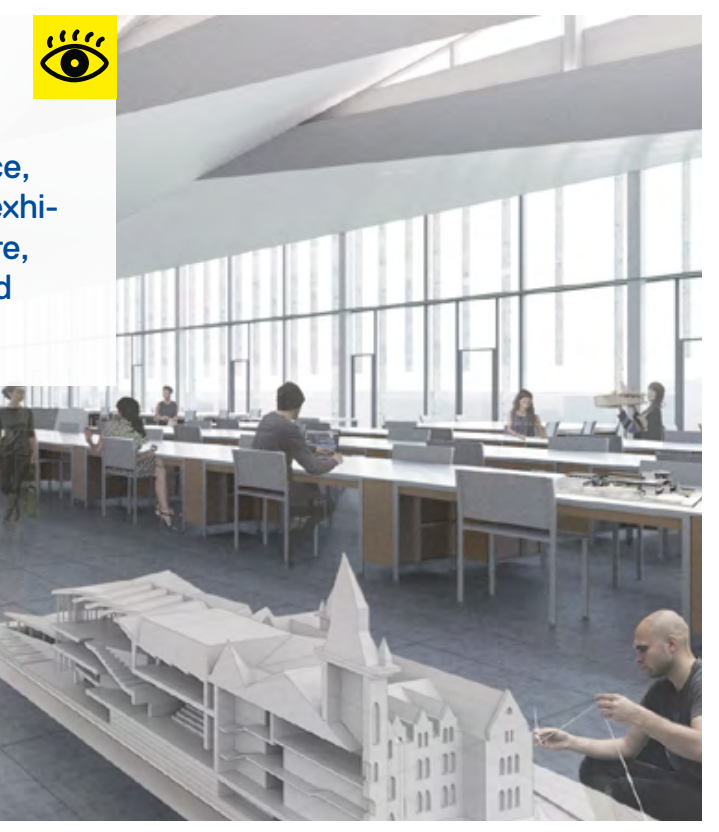

\section{Library}

A new library space dedicated to architecture and urbanism will provide collaborative work spaces, teaching facilities, and a dedicated section for the University's rare book collection.

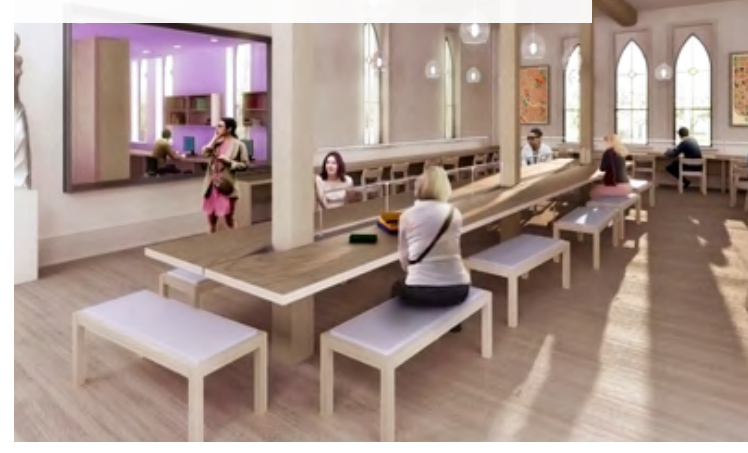

\section{Pedestrian Connections}

The central corridor of One Spadina acts as an extension of Russell Street, and helps to connect the university campus with the surrounding neighbourhood.

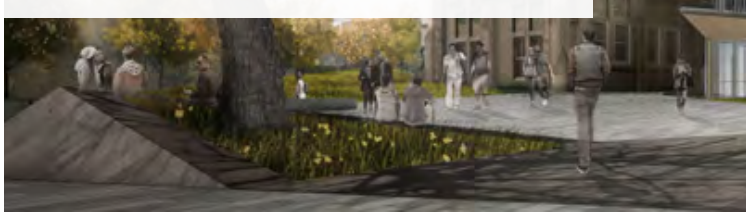

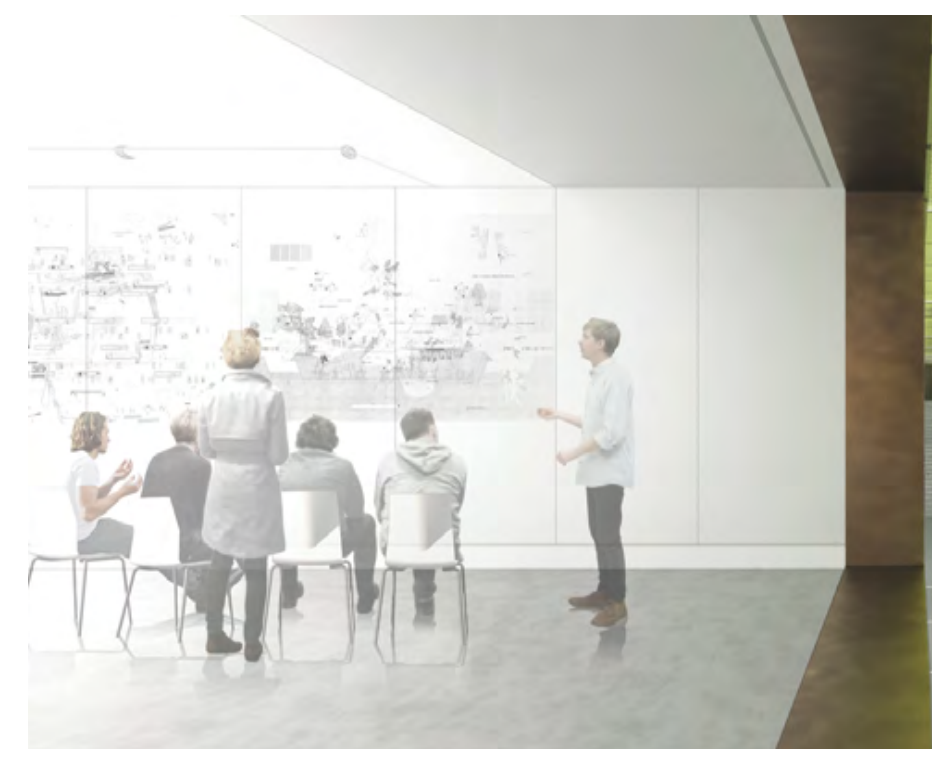

Innovation Labs and Research Facilities

A Digital Fabrication Lab, the Global Cities Institute, the Green Roof Testing Lab, and the Responsive Architecture Lab are among the multidisciplinary research facilities that will be housed in the new building. 


\section{The Theatre Centre}

Since 1979, the

Theatre Centre

has been a live arts incubator. Currently housed in a historic Carnegie Library building, the Theatre Centre has become an important hub forToronto's cultural sector. ${ }^{48}$

\section{History}

Originally founded as a cooperative of five independent theatre companies, the Theatre Centre serves as a space to create, develop, rehearse, and present new theatrical performances. The Theatre Centre moved to various locations in Toronto for decades before finding its current home in a former Carnegie Library building on Queen Street West. 49

Designed by architect Robert McCallum in 1908, the Edwardian heritage building

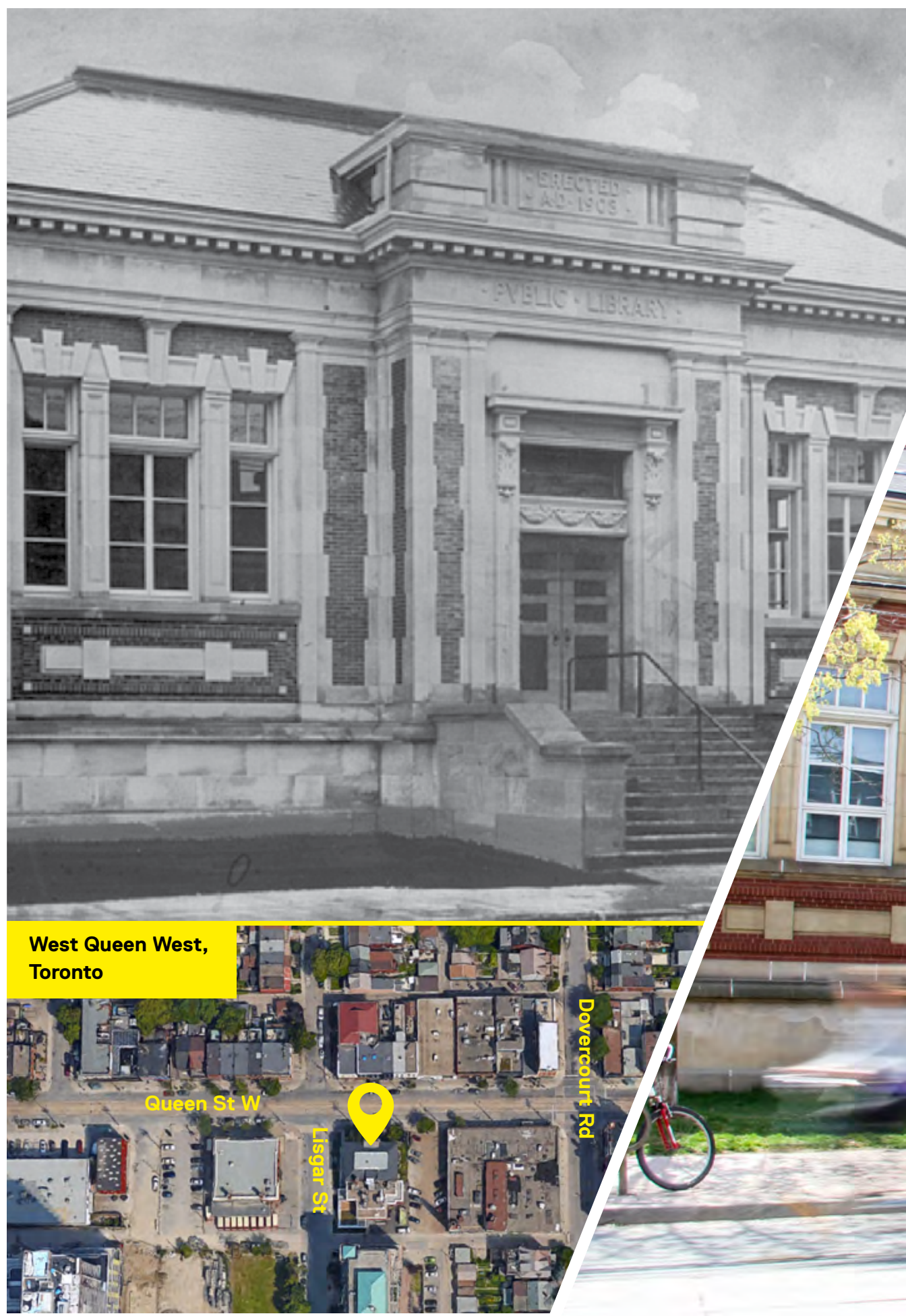


1908

Original

Carnegie Library building built

1979

Theatre Centre founded

2014

Theatre Centre opens in its new home
200

Seats in

the Theatre

Centre's main performance space

\section{\$6.2 million}

Cost of redevelopment project ${ }^{50}$

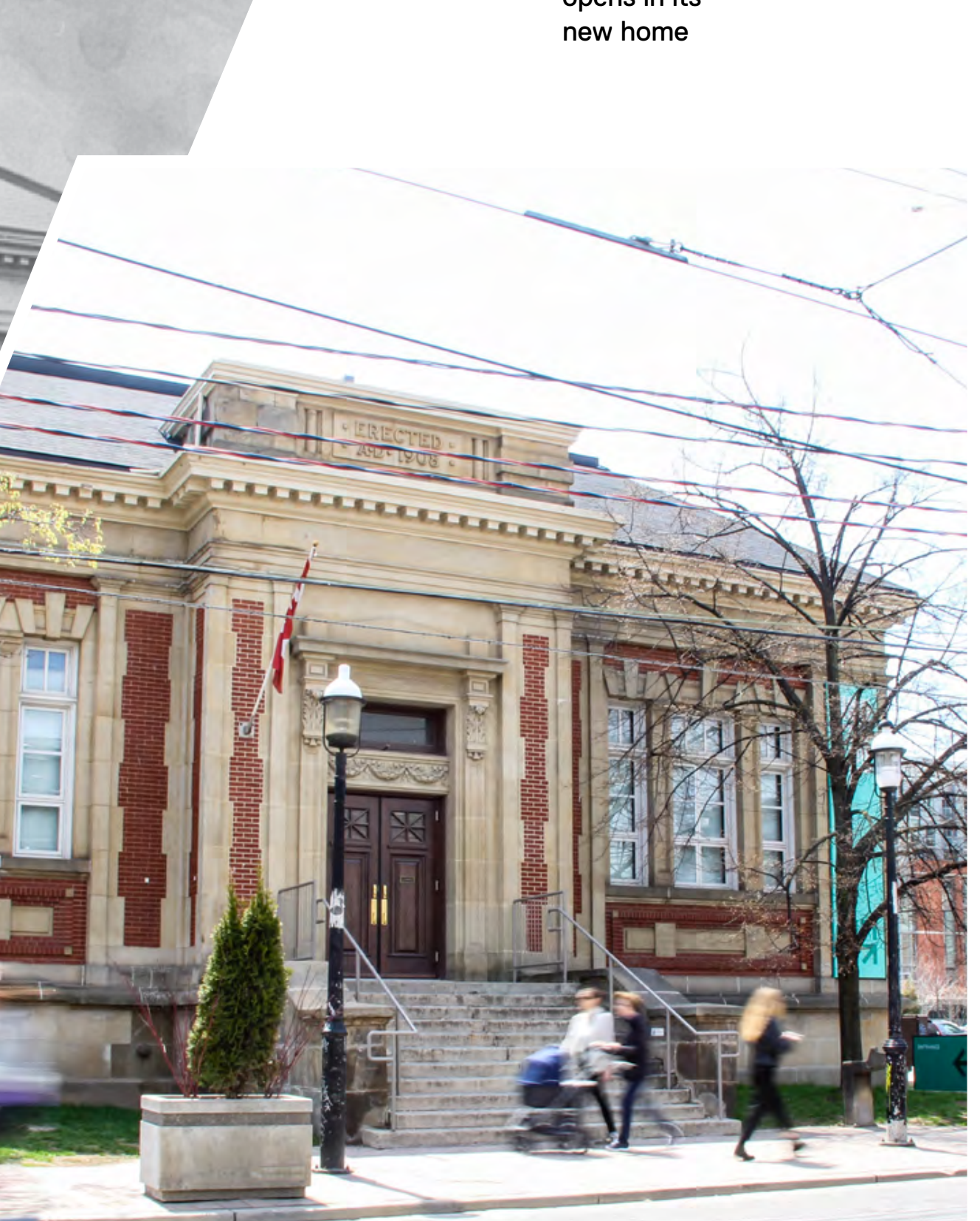

originally served as a public library until the mid-1960s when it contained public health offices. In 2012, the Theatre Centre embarked on a $\$ 6.2$ million adaptive reuse and restoration project and settled into its new permanent home in $2014 \cdot{ }^{51}$

\section{Redesign}

As part of a major privatelyled redevelopment initiative, the historic Carnegie Library building was preserved and maintained for public and cultural use. With the City as a stakeholder in the redevelopment plan, and catalyzed by input from neighbouring organizations, the importance of a vibrant cultural community in this area was recognized. Contributions from developers were secured partially through Section 37 community benefits agreements to fund the renovation of the structure for use as a cultural facility. ${ }^{52}$

Preserving the public value and providing public access to the building were fundamental principles of its transformation. The facade was preserved by a modest modern addition at the west side of the structure, while the interior now accommodates a 200-seat performance venue, rehearsal spaces, galleries, event spaces, and a cafe. 


\section{Operating Structure}

The Theatre Centre is a non-profit and registered charitable organization.

\section{Financing Structure}

Section 37 contributions provided early financial stability to offset the risks in getting this project off the ground. ${ }^{53} \mathrm{Key}$ funding partners for the capital cost of renovations included Provincial and Federal levels of government, as well as a number of private donations from TD Bank, the Metcalf Foundation, and the developers Urbancorp and Streetcar. ${ }^{54}$ In addition to continued support from government partners, the operating budget is supported by ticket sales, fees for private events, and revenue from the cafe.
Monthly

\section{Community Meals}

Every month, the Cafe invites neighbours for a community dinner, hosted by the Theatre Centre's Director of Productions and Facilities. ${ }^{55}$

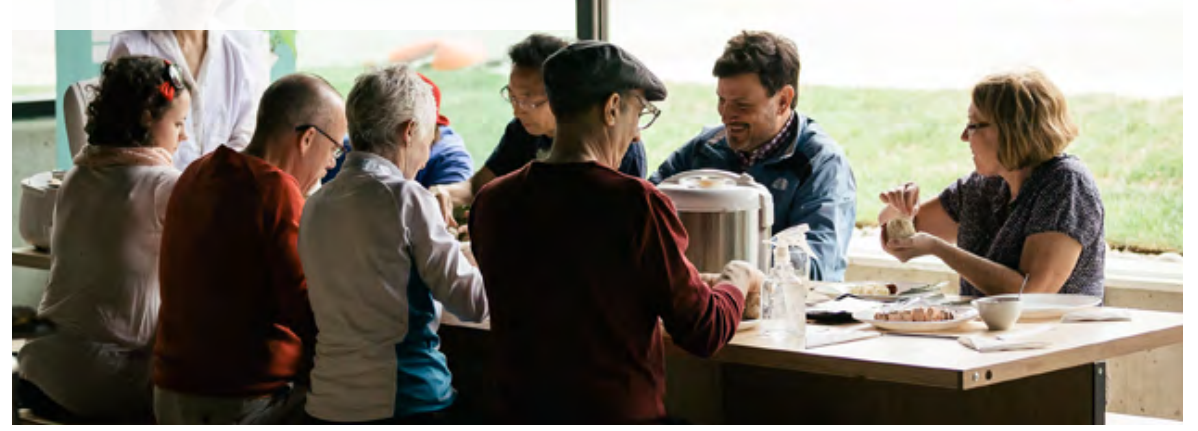

\section{Temporary} Installations

In keeping up with the Theatre Centre's open and accessible philosophy, the Cafe features floor-to-ceiling windows, which allow the space to display temporary hanging art installations underits "Side Streets" program. ${ }^{57}$
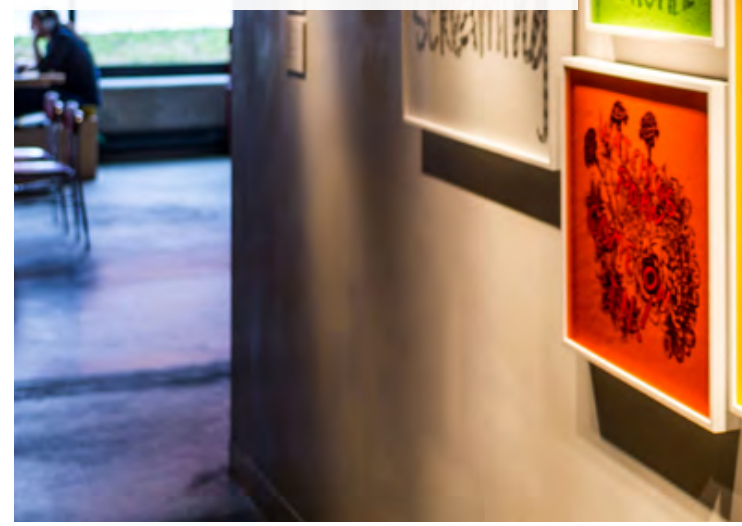

\section{Cinq a Sept Cocktail Nights}

Every third Thursday, the Cafe hosts an after-work cocktail mixer. The event provides a platform for guest bartenders to show off their signature concoctions and gives attendees a chance to network with other creative professionals.

\section{Theatre Space}

The Theatre Centre houses two full-sized theatre spaces that are used for performances, festivals, and special events year-round. In recognition of the Theatre Centre's past without a stable venue, the Centre offers its facilities to emerging theatre companies and performance groups. ${ }^{56}$

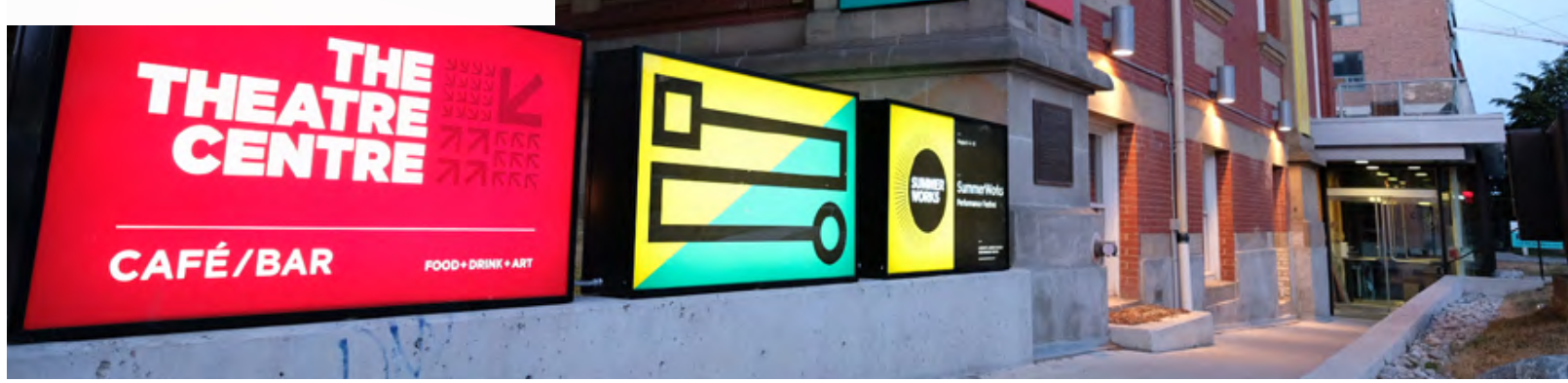




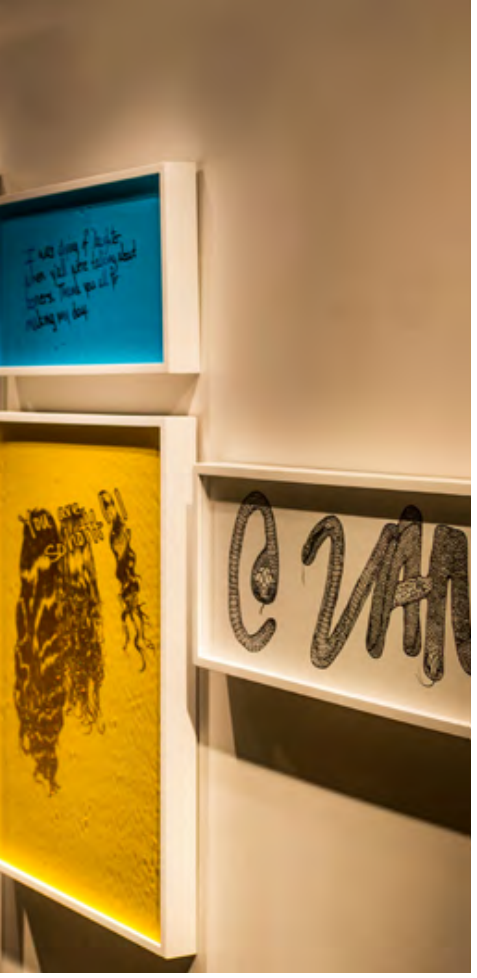

Community

Collaborations and

Special Events

The Theatre Centre's flexible space makes it the ideal venue for special events, including the popular City of Craft holiday market. ${ }^{58}$

$1=$
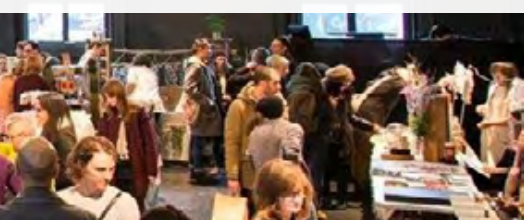

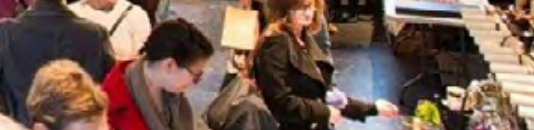

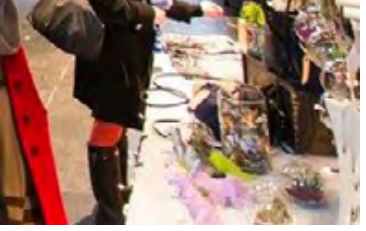

\section{LESSONS FOR OLD CITY HALL}

\section{One of the Theatre Centre's} core objectives is to position the performing arts as an accessible medium, rather than culture for the elite. This focus on welcoming the public is reflected in its accessible arts programs and in the building's redesign.

As the primary reception area, the Cafe is a popular pre-performance gathering spot for theatre attendees. The space also invites the public to come in for an afternoon coffee, a monthly community dinner, or a cocktail hour. The Cafe also acts as a gallery space for the works of local visual artists, inviting another community into the space.

The programs presented by the Theatre Centre position the space as an accessible and publicly engaged community resource. By supporting experimentation for artists-in-residence, promoting public access to its rehearsal and performance spaces, and hosting special community events, the Theatre Centre has carved out an important cultural space as part of the West Queen West community. 
MoMA PS1

A true artistic laboratory located in an adapted New York City public school, MoMA PS1 is one of the largest American institutions devoted to exhibiting experimental contemporary art. ${ }^{59}$

\section{History}

Founded in 1971, the Institute for Art and Urban Resources was devoted to featuring contemporary art in abandoned or underused sites throughout the city. The transformation from the Institute for Art and Urban Resources to MoMA PS1 began in 1976, when the Institute created its first installation in what eventually became its permanent home: a Romanesque Revival public school building in Queens, constructed in $1892 .{ }^{60}$

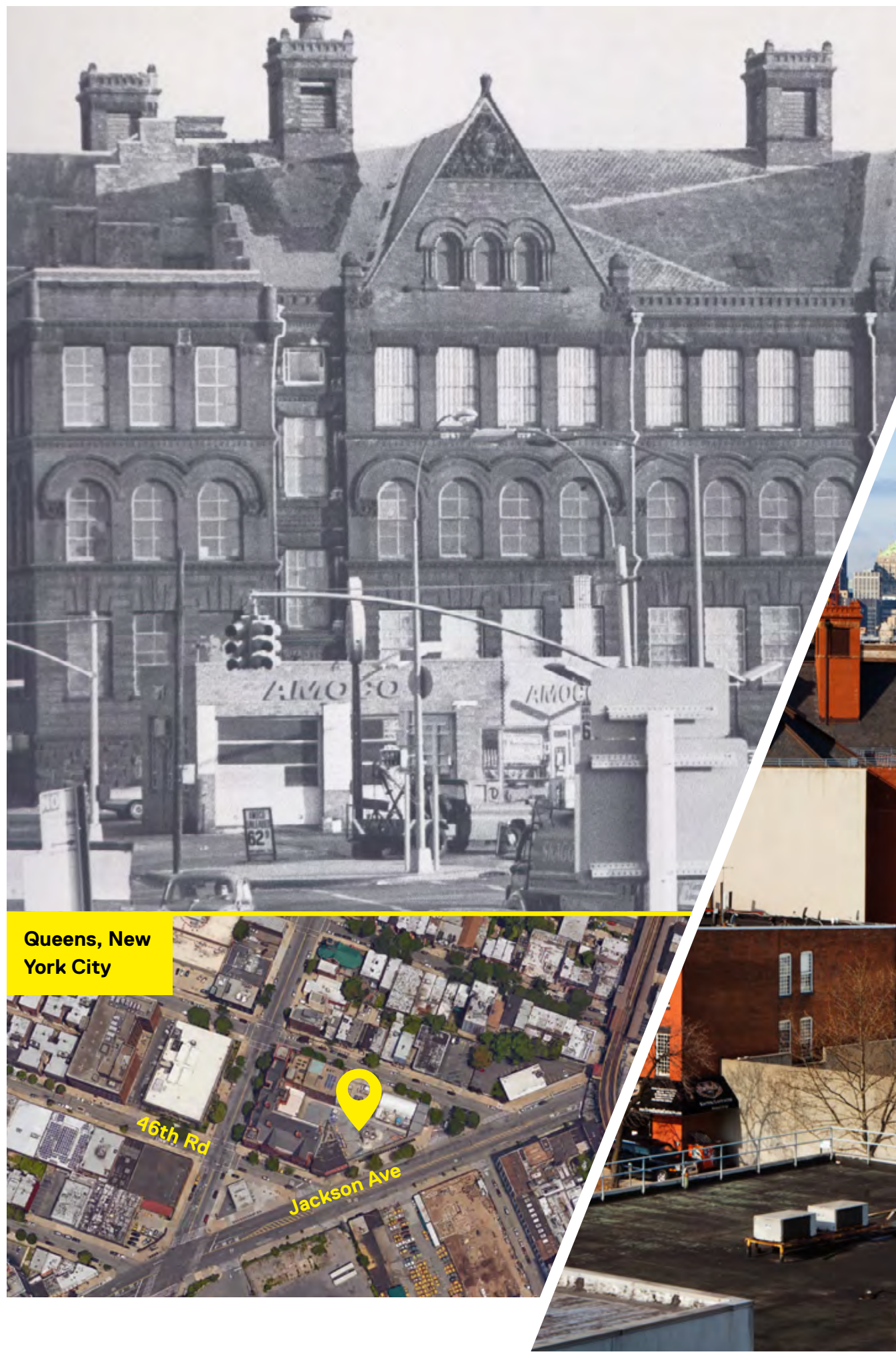


1971

Institute for

Art and Urban

Resources Inc.

founded

1976

First major

exhibition

launched in

former public

school in Long

Island City,

Queens
2010

PS1 Contempo-

rary Art Centre

merges with

MoMA

125,000 sq. ft.

Area of MoMA

PS1 facility

2,000+

Artists whose

work has been

mounted at PS1 ${ }^{61}$

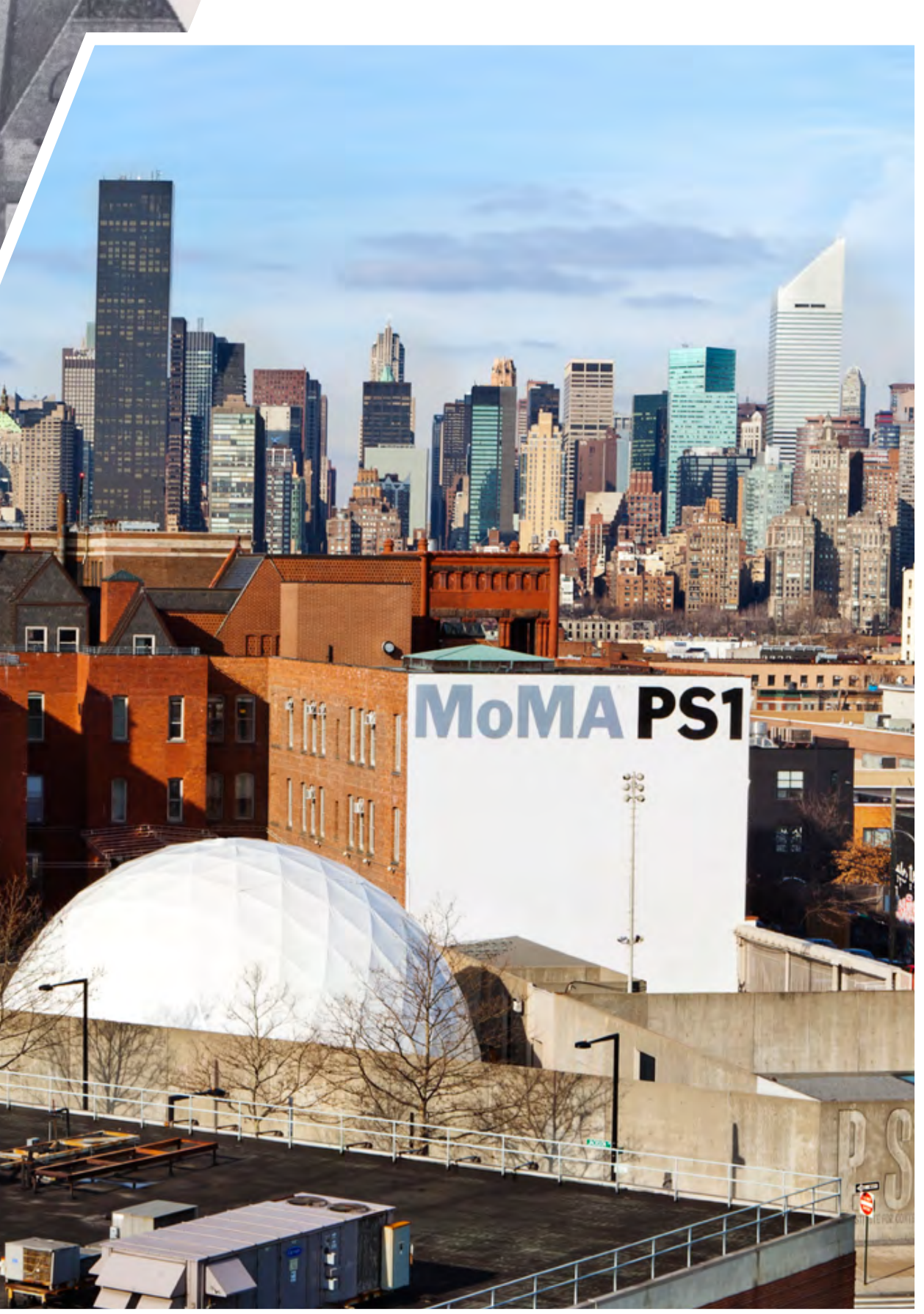




\section{Operating Structure}

While the building is still owned by the City of New York, as of 2010 the gallery space is an official affiliate of the Museum of Modern Art (MoMA) and operates as a non-profit organization, governed by an independent board of governors.

\section{Financial Structure}

MoMA PS1's programs, activities, and exhibits rely on a variety of funding sources. These include revenues from tickets sales and memberships, small and large donations, grants, and sponsorships. ${ }^{65}$ Some exhibitions receive additional support through a combination of corporate and philanthropic donations. For example, the Annual Exhibition benefits from a partnership with Volkswagen while the museum's institutional archive is supported by funding through the Leon Levy Foundation.
The Young Architects Program

This annual competition receives submissions for site-specific interventions to animate the space surrounding PS1, creating a platform to promote innovative installations from emerging architects. Successful applicants get to design a temporary urban landscape that provides shade, seating, and water for the Warm Up summer music series hosted in the PS1's courtyard.
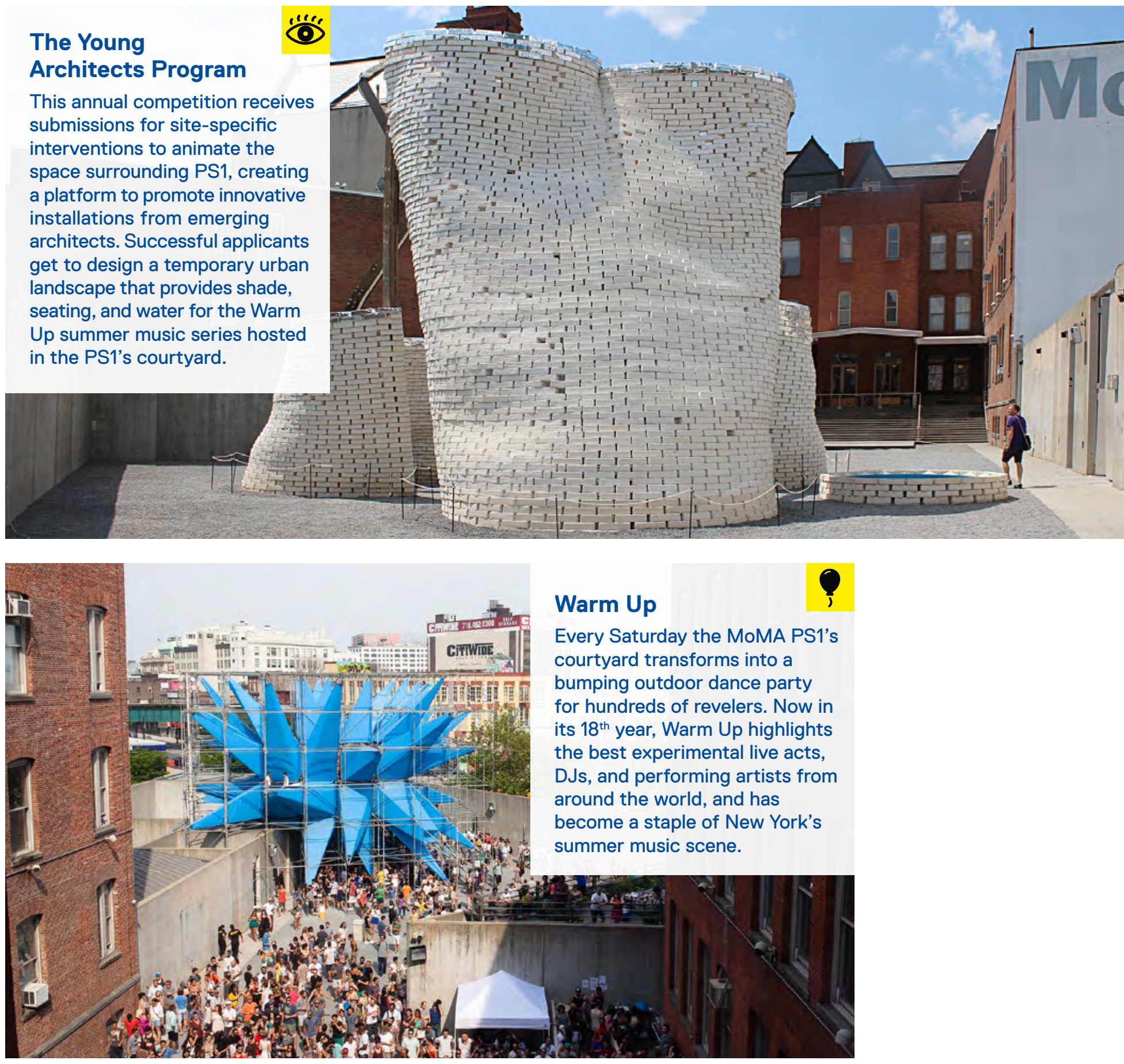


\section{LESSONS FOR OLD CITY HALL}

PS1's unique approach to its use of its historic home is evident in its inaugural 1976 M. Wells Dinette Cafe

\section{$\underline{\underline{p}}$}

The M. Wells Dinette brings back memories of grade school lunches in its former elementary school setting, chalkboards included. The culinary offerings of the Dinette are as cutting edge and inspired as the artworks in the rest of the museum.

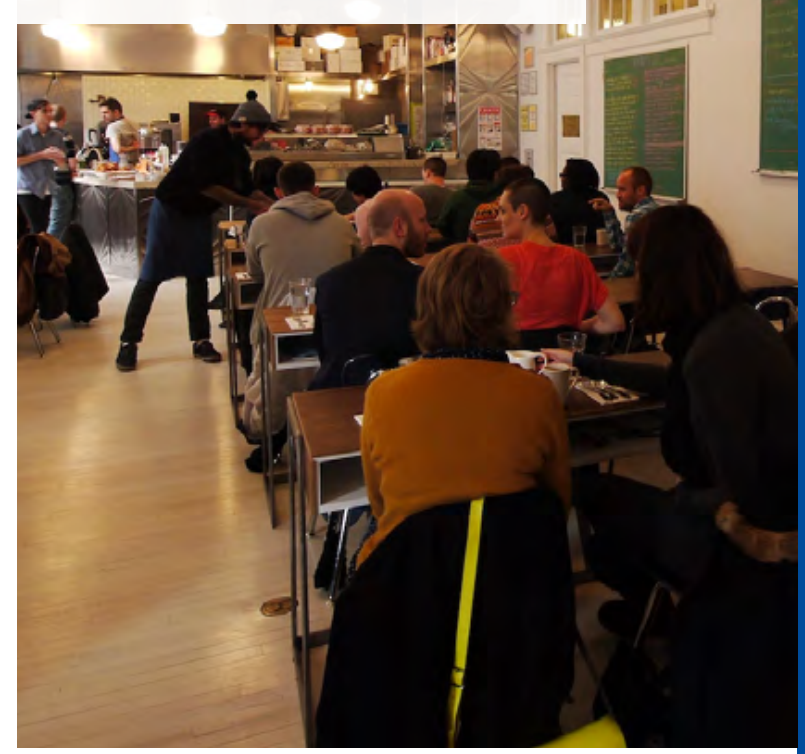

exhibition, Rooms. The Rooms exhibition called on 72 artists to create site-specific works for many of the small, former classroom spaces. This set a precedent for the display of works in smaller gallery spaces.

Interesting parallels can be drawn to Toronto's Old City Hall, as one of the major constraints for its adaptive reuse is the load-bearing walls and relatively small existing courtroom and office spaces. ${ }^{66} \mathrm{PS} 1$ 's creative use of its smaller interior spaces highlights the opportunity to work with an existing layout, maintain the integrity of a historic interior, and create an engaging visitor experience.

Beyond its walls, PS1's Warm Up outdoor festival series presents an exciting example of what is possible for Old City Hall. Its existing courtyard space could bridge the gap between Trinity Square and Eaton Centre and City Hall and Nathan Phillips Square, positively expanding the area's broader public realm network. 


\section{The Royal \\ Conservatory \\ of Music

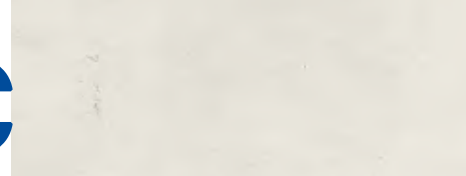

The elegant combination of heritage and contemporary architectural styles between The Telus Centre for Performance and Learning and The Royal Conservatory of Music create a standout contribution to the burgeoning Bloor Street cultural corridor.

\section{1}

Toronto Baptist College building constructed near Bloor St. and University Ave.

1886

Toronto

Conservatory of Music is founded
1947

The Conservatory of Music receives the Royal Charter from King George VI

\section{9}

The Conservatory expansion and redevelopment is completed
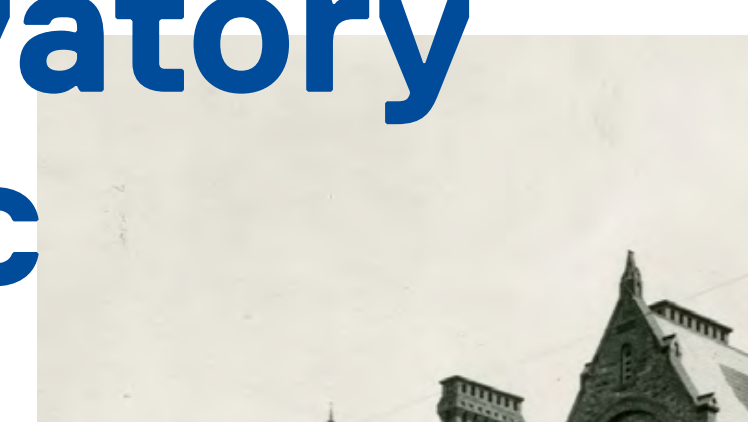

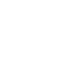




\section{Operating Structure}

The Royal Conservatory is a music education institution rather than a museum. It operates as a not-for-profit organization and develops research and curriculum related to arts-based education for all ages and skill levels. Among the RCM's more than five million alumni are Canadian music legends Glenn Gould, Oscar Peterson, and Sarah McLachlan. ${ }^{69}$

\section{Financial Structure}

The RCM is largely funded by private donations, and revenue from concert tickets and music lessons. Unlike Toronto's other premier cultural institutions, such as the Art Gallery of Ontario or the Royal Ontario Museum, the RCM is not a government agency. ${ }^{70}$ Telus was the lead sponsor for the RCM's recent $\$ 110$ million renovation and expansion.
The RCM also obtained a $\$ 20$ million loan from the joint federal and provincial SuperBuild Program to support the project. ${ }^{71}$ With $\$ 4.5$ million in loan repayments in 2015 , nearly 10 per cent of the RCM's annual budget, the organization is challenged to balance its financial obligations with its commitment to providing a world-class music education.

\section{Learning}

Through the Arts

The RCM is home to one of the world's most replicated and respected arts-based education programs.

\section{Koerner Hall}

With more than 1100 seats, Koerner Hall is larger than the concert hall originally proposed in the RCM's revitalization project, and was a significant factor in the increased budget. However, most concert-goers agree that its elegance and warm acoustics were worth it.
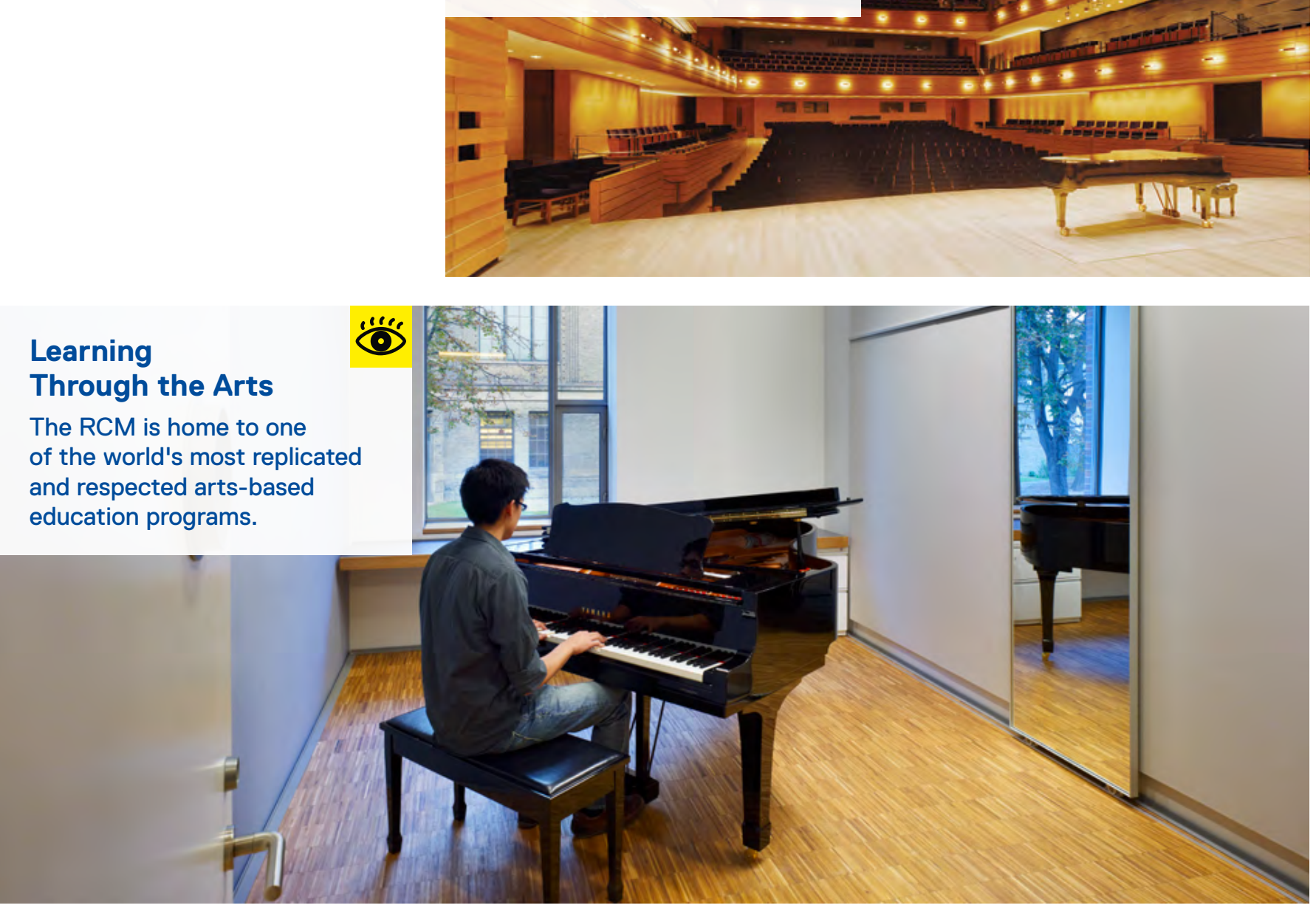


\section{Private Events}

The Royal Conservatory is also available as a private event venue. The conservatory theatre, atrium, Koerner Hall and Leslie and Anna Dan Gallerias, are all available to accommodate various sizes and types of events, from cocktail parties and dinners to recitals, public debates, and lectures.

\section{Mazzoleni Concert Hall}

For a more intimate atmosphere, the historic Mazzoleni Hall provides a classical concert hall that seats almost 250 .

\section{LESSONS FOR OLD CITY HALL}

Modern additions to historic buildings can be controversial, both functionally and aesthetically. The Telus Centre for Performance and Learning hit the mark on both counts.

On the inside, Koerner Hall's suspended wood ribbon ceiling is both aesthetically and acoustically phenomenal. From the outside, the way that the atrium links the new addition and heritage structures is equally beautiful. The integration of heritage and contemporary components creates a wonderful public face that responds to its context from both Bloor Street and Philosopher's Walk.

Old City Hall presents similar opportunities to create dynamic and inspiring thresholds to the surrounding public realm as well as interior spaces to match. There are three public faces to be activated: the historic grandeur of the main staircase and facade on Queen Street; the secondary frontages which face onto Bay, James and Albert Streets; as well as the internal courtyard which offers the chance to create an entirely new experience for Torontonians in the heart of Canada's largest city. 


\section{Endnotes}

1 City of Toronto. City Council Decision-GM7.5 Old City Hall Future Tenant Options. 3 November 2015. http://app.toronto.ca/tmmis/viewAgendaItemHistory.do?item $=2015 \cdot G M 7 \cdot 5$

2 CS\&P Architects. Old City Hall Future Uses Study \& Feasibility of Toronto Museum Project. Prepared for City of Toronto Economic Development \& Culture and Facilities Management, Energy \& Strategic Initiatives. 2010.

3 Lord Cultural Resources. Toronto Museum Project: Update to the Business Plan. 2008; Toronto Historical Board. Civic Museum Task Force Report. 1986; CS\&P Architects. Old City Hall Future Uses Study \& Feasibility of Toronto Museum Project. Prepared for the City of Toronto. 2010, p. 1.

4 Museum of the City of New York. Biennial Report: 2013/2014. 2015.

5 Museum of the City of New York online. About the City Museum. Accessed July 15, 2016: http://www. mcny.org/?q=content/about-city-museum

6 Personal Correspondence with Daphne Yuen, Museum of the City of New York Researcher, via Email. July/August 2016.

7 Museum of the City of New York online. About the City Museum. Accessed July 15, 2016: http://www. mcny.org/?q=content/about-city-museum

8 Museum of the City of New York. Biennial Report: 2013/2014. 2015 .

9 Museum of the City of New York. Biennial Report: 2013/2014. 2015 .

1o Museum of the City of New York. Biennial Report: 2013/2014. 2015 .

11 Canadian Centre for Architecture online. Explore. Accessed August 03, 2016. http://www.cca.qc.ca/ en/explore

12 Canadian Centre for Architecture online. CCA History. Accessed August 02, 2016. http://www. cca.qc.ca/en/37311/cca-history

13 Canadian Centre for Architecture online. About. Accessed August 02, 2016. http://www.cca.qc.ca/ en/about

14 Canadian Centre for Architecture online. About. Accessed August 02, 2016. http://www.cca.qc.ca/ en/about

15 Canadian Centre for Architecture online. About. Accessed August 02, 2016. http://www.cca.qc.ca/ en/about

16 Canadian Centre For Architecture online. About. Accessed July 24, 2016. http://www.cca.qc.ca/en/ about
17 City of Berlin online. About Us. Accessed August 16, 2016. http://www.stadtentwicklung.berlin.de/ wir_ueber_uns/index_en.shtml

18 Urban Catalyst. The Power of Temporary Use. Dom Oublishers, Berlin, Germany. 2014.

19 City of Berlin online. City Models of Berlin / Senate Department for Urban Development and the Environment. Accessed August 16, 2016. http://www.stadtentwicklung.berlin.de/planen/ stadtmodelle/en/ausstellung.shtml

2o City of Berlin online. City Models Digital City / Senate Department for Urban Development and the Environment. Accessed August 16, 2016. http:// www.stadtentwicklung.berlin.de/planen/ stadtmodelle/de/digitale_innenstadt/index.shtml

${ }_{21}$ City of Berlin online. About Us / Senate Department for Urban Development and the Environment. Accessed August 02, 2016. http://www. stadtentwicklung.berlin.de/wir_ueber_uns/ index_en.shtml

22 City of Berlin online. City Model "Historic Centre" in Scale 1:50o. Accessed August 12, 2016. http:// www.stadtentwicklung.berlin.de/planen/ stadtmodelle/en/stadtmodell_5oo.shtml

23 City of Berlin online. Model of the former GDR-City Centre in Scale 1:50o. Accessed August 12, 2016. http://www.stadtentwicklung.berlin.de/planen/ stadtmodelle/en/planmodell_ddr.shtm

24 City of Berlin online. Talkng City Model in Scale 1:200. Accessed August 12, 2016. http://www. stadtentwicklung.berlin.de/planen/stadtmodelle/ en/tastmodell_20oo.shtml

25 City of Berlin online. City Model in Scale 1:500. Accessed August 12, 2016. http://www. stadtentwicklung.berlin.de/planen/stadtmodelle/ en/stadtmodell_10oo.shtml

26 Design Exchange online. History + Founders / Design Exchange. Accessed August 03, 2016. http://www.dx.org/index.cfm?pagepath=About_ DX/History_Founders\&id $=42887$

${ }_{27}$ Design Exchange online. About DX. Accessed August 03, 2016. http://www.dx.org/index. cfm?pagepath $=$ About_DX\&id $=42862$

28 Design Exchange online. History + Founders / Design Exchange. Accessed August 03, 2016. http://www.dx.org/index.cfm?pagepath=About_ DX/History_Founders $\&$ id $=42887$

29 Design Exchange online. History + Founders / Design Exchange. Accessed August 03, 2016. http://www.dx.org/index.cfm?pagepath=About DX/History_Founders\&id $=42887$

3o City of Toronto. Staff Report-ED3.7 Operating Support for the Design Exchange (DX). 25 March, 2015. http://www.toronto.ca/legdocs/mmis/2015/ ed/bgrd/backgroundfile-78711.pdf
31 City of Toronto. Staff Report - ED8.4 Design Exchange (DX) Operation \& Funding Update. 26 October, 2015. http://www.toronto.ca/legdocs/ mmis/2015/ed/bgrd/backgroundfile-85596.pdf

32 Personal correspondence with Shauna Levy, Design Exchange President and CEO, via telephone. June 29, 2016.

33 City of Toronto. City Council Decision - ED3.7 Operating Support for the Design Exchange (DX). 16 April 2015. http://app.toronto.ca/tmmis/ viewAgendaItemHistory.do?item $=2015 . E D 3.7$

34 Personal correspondence with Shauna Levy, Design Exchange President and CEO, via telephone. June 29, 2016.

35 Design Exchange online. Permanent Collection. Accessed August 03, 2016. http://www.dx.org/ index.cfm?pagepath=

Permanent_Collection\&id $=42904$

36 Personal correspondence with Shauna Levy, Design Exchange President and CEO, via telephone. June 29, 2016.

37 Design Exchange online. Visit DX. Accessed August 03, 2016. http://www.dx.org/index. $\mathrm{cfm}$ ?pagepath $=$ Visit $\& \mathrm{id}=42841$

38 CS\&P Architects. Old City Hall Future Uses Study \& Feasibility of Toronto Museum Project. Prepared for City of Toronto Economic Development \& Culture and Facilities Management, Energy \& Strategic Initiatives. 2010, p. 35.

39 Golden, Anne, Leon Kossar, Bruce Lawson, and Dean Smith. Report from the Mayor's Task Force on Old City Hall. 1973.

40 City of Toronto. Staff Report-GM7.5 Old City Hall: Future Tenant Options. 21 September 2015. http:// www.toronto.ca/legdocs/mmis/2015/gm/bgrd/ backgroundfile-84009.pdf

41 Preservation Green Lab at the National Trust for Historic Preservation. The Greenest Building: Quantifying the Environmental Value of Building Reuse. 2011.

42 The University of Toronto. The Campaign for the John H. Daniels Faculty of Architecture, Landscape, and Design. ND.

43 The University of Toronto. The Campaign for the John H. Daniels Faculty of Architecture, Landscape, and Design. ND.

44 John H. Daniels Faculty of Architecture, Landscape and Design online. Fact Sheet. Accessed June 28, 2016: https://www.daniels. utoronto.ca/fact-sheet-one-spadina

45 John H. Daniels Faculty of Architecture, Landscape and Design online. Campaign Initiatives. Accessed July 25, 2016: http:// boundless.utoronto.ca/divisions/john-h-daniels-faculty-of-architecture-landscape-and-design/ 
46 John H. Daniels Faculty of Architecture, Landscape and Design online. Fact Sheet. Accessed June 28, 2016: https://www.daniels. utoronto.ca/fact-sheet-one-spadina

47 John H. Daniels Faculty of Architecture, Landscape and Design online. Fact Sheet. Accessed June 28, 2016: https://www.daniels. utoronto.ca/fact-sheet-one-spadina

${ }_{48}$ The Theatre Centre online. About. Accessed August 02, 2016. http://theatrecentre.org/? $\mathrm{p}=3656$

49 The Theatre Centre online. About. Accessed August 02, 2016. http://theatrecentre.org/?p=3656

so The Theatre Centre online. About. Accessed August 02, 2016. http://theatrecentre.org/?p=3656

${ }_{51}$ The Theatre Centre online. Our New Home. Accessed August 02, 2016. http://theatrecentre. org $/$ p $=3686 \&$ preview $=$ true

52 Davis, Meaghan. Sec. 37 of the Creative City, How density Bonus have secured Cultural Benefits in the City of Toronto. Toronto Ontario, Ryerson University Masters Major Research Paper: 2016.

53 Davis, Meaghan. Sec. 37 of the Creative City, How density Bonus have secured Cultural Benefits in the City of Toronto. Toronto Ontario, Ryerson University Masters Major Research Paper: 2016.

54 Nestruck, J. Kelly. "A new development in downtown Toronto - and this one's for artists." The Globe and Mail. March 21, 2014. http://www. theglobeandmail.com/news/toronto/a-new-development-on-torontos-queen-west---for-artists/ article17616837/

55 The Theatre Centre online. Café/Bar. Accessed August 02, 2016. http://theatrecentre. org $/ ? \mathrm{p}=6024$

${ }_{56}$ The Theatre Centre. Programming. Accessed June 28, 2016: http://theatrecentre.org/?p=3743

57 The Theatre Centre online. Café/Bar. Accessed August 02, 2016. http://theatrecentre. org $/$ ? $=6024$

${ }_{58}$ The Theatre Centre online. Café/Bar. Accessed August 02, 2016. http://theatrecentre. org $/$ ? $=6024$

59 MOMA PS1 online. About MOMA PS1. Accessed August 2: http://momaps1.org/about/

6o MoMA online. MoMA.org/Interactives / Exhibitions / The Artist in Place: The First Ten Years of MoMA PS1. Accessed August 10, 2016. https://www. moma.org/interactives/exhibitions/2012/ artistinplace/

61 MoMA PS1 online. Statement of Affiliation. Accessed August 11, 2016. http://momaps1.org/ about/affiliation/

62 MoMA PS1 online. Statement of Affiliation. Accessed August 11, 2016. http://momaps1.org/ about/affiliation/
63 MoMA online. MoMA.org/Interactives / Exhibitions / The Artist in Place: The First Ten Years of MoMA PS1. Accessed August 10, 2016. https://www. moma.org/interactives/exhibitions/2012/ artistinplace/

64 MoMA PS1 online. About MOMA PS1. Accessed August 02, 2016: http://momaps1.org/about/

${ }_{55}$ MoMA PS1 online. Support MoMA PS1. Accessed August 12, 2016. http://momaps1.org/support/

66 Golden, Anne, Leon Kossar, Bruce Lawson, and Dean Smith. Report from the Mayor's Task Force on Old City Hall. 1973, p. 3.

67 The Royal Conservatory of Music online. Historical Timeline. Accessed September 02, 2016. http://www.rcmusic.ca/historical-timeline

68 KPMB Architects online. Koerner Concert Hall, Royal Conservatory. Accessed September 02, 2016 http://www.kpmbarchitects.com/index. asp? navid $=30 \&$ fid $1=50 \&$ fid $2=87 \&$ fid $3=32 \& \mathrm{~min}-$ year $\mathrm{x}=\&$ maxyear $\mathrm{x}=\#$ desc

69 The Royal Conservatory of Music online. Overview. Accessed September 02, 2016. http:// www.rcmusic.ca/overview

7o Knelman, Martin. "Exclusive: Royal Conservatory of Music seeks bailout on \$75M loan." Toronto Star. 8 March, 2016. https://www.thestar.com/ entertainment/2016/03/o8/exclusive-royal-conservatory-of-music-seeks-bailout-on-75m-loan. html

71 Knelman, Martin. "Exclusive: Royal Conservatory of Music seeks bailout on \$75M loan." Toronto Star. 8 March, 2016. https://www.thestar.com/ entertainment/2016/03/o8/exclusive-royal-conservatory-of-music-seeks-bailout-on-75m-loan. html 


\section{Image Credits}

Cover

- Photo - Bay Street, Toronto: Anthony Sotomayor, used with permission.

- Photo - MoMA PS1: MOMA PS1 Warmup by Dan Nguyen, licensed under CC BY 2.0, via Flickr.

Pg 2-3

- Photo - Old City Hall: Sam Carter-Shamai, used with permission.

- Photo - Old City Hall Courthouse: Sam Carter-Shamai, used with permission.

Pg 4-5

- Photo: Sam Carter-Shamai, used with permission.

- Map: Google Earth.

Pg 6-7

- Photo - Berlin Senate Department for Urban Development and the Environment: Sam Carter-Shamai, used with permission.

- Photo - Canadian Centre for Architecture: Sam Carter-Shamai, used with permission.

Pg 8-9

- Photo - Design Exchange: Design Exchange, used with permission.

- Photo - Berlin Senate Department for Urban Development and the Environment: Sam Carter-Shamai, used with permission.

- Photo - Museum of the City of New York: Daphne Yuen, used with permission.

- Photo-Canadian Centre for Architecture: Landscapes of the Hyperreal:

Ábalos ¿ Herreros selected by SO - IL, installation view, 2015. Photograph (C) CCA, Montréal. Used with permission.

Pg 10-11

- Historic photo: Wuts Bros. (New York, NY.)/Museum of the City of New York. X2010.7.2.23313. Used with permission.

- Map: Google Earth.

- Contemporary photo: Daphne Yuen, used with permission.

\section{Pg 12-13}

- Photo - Temporary Exhibitions: MichaelGericke GD 003 by MichaelGericke,

licensed under CC BY 2.0, via Flickr.

- Photo-Special Events: Daphne Yuen, used with permission.

- Photo - Neighbourhood Programs: Philip Wolak, used with permission.

Pg 14-15

- Historic photo: Sam Carter-Shamai, used with permission.

- Map: Google Earth.

- Contemporary photo: View of south elevation showing Alcan Scholars' Wing (1989, Peter Rose architect) and Shaughnessy House (1874, W.T. Thomas, architecte). Canadian Centre for Architecture Collection, Montréal. (c) CCA, Montréal. Used with permission.

Pg 16-17

- Photo - Vernissage: Álvaro Siza: Punt en Komma, lecture, September 2015. Photograph (C) CCA, Montréal. Used with permission.

- Photo-Bookstore: View of the CCA Bookstore. (c) CCA, Montréal. Used with permission.

- Photo - Research and Archives: Cornell University design studio with Yoshiharu Tsukamoto, April 2013. Photograph (C) CCA, Montréal. Used with permission.

- Photo - Exhibitions and Publications: Rooms You May Have Missed: Umberto Riva, Bijoy Jain, workshop-visit, March 2015. Photograph (C) CCA, Montréal. Used with permission.

- Photo - The Architecture Garden and Museum Grounds: Movies under the Stars, July 2016. Photograph (C) CCA, Montréal. Used with permission.

Pg 18-19

- Historic photo: Wolfgang Bittner, Landesdenkmalamt Berlin, used with permission.

- Map: Google Earth.

- Contemporary photo: Sam Carter-Shamai, used with permission.

Pg 20-21

- Photo - "Historic Centre" City Model: Sam Carter-Shamai, used with permission.

- Photo - Former GDR-City Centre at 1:5oo scale: Sam Carter-Shamai, used with permission.
- Photo - Talking City Model: Sam Carter-Shamai, used with permission.

- Photo - City Model: Sam Carter-Shamai, used with permission.

Pg 22-23

- Historic photo: Design Exchange, used with permission.

- Map: Google Earth.

- Contemporary photo: Design Exchange, used with permission.

Pg 24-25

- Photo - Private Events: Design Exchange, used with permission.

- Photo-Permanent Collection: Design Exchange, used with permission.

- Photo - Exhibitions: Design Exchange, used with permission.

- Photo-Off-Site Events: Design Exchange, used with permission.

Pg 26-27

- Photo - Museum of the City of New York: Amsterdam / New Amsterdam, by Michael Gericke, licensed under CC BY 2.0, via Flickr.

- Photo - The Theatre Centre: Sam Carter-Shamai, used with permission.

Pg 28-29

- Photo - MoMA PS1: MoMA PS1 YAP by Forgemind Archimedia, licensed under $\underline{\mathrm{CC}}$ BY 2.0, via Flickr.

- Photo - The Royal Conservatory of Music: Sam Carter-Shamai, used with permission.

- Photo - One Spadina Crescent: NADAAA, used with permission.

- Photo - The Theatre Centre: The Theatre Centre by Kaycee49, licensed under CC BY 4.0, via Wikimedia Commons.

Pg 30-31

- Historic photo: The Daniels Faculty of Architecture at the University of Toronto, from NADAAA, used with permission.

- Map: Google Earth.

- Rendering: NADAAA, used with permission.

Pg 32-33

- All renderings: NADAAA, used with permission. (John H. Daniels Faculty of Architecture, Landscape and Design. Fact Sheet. Accessed June 28, 2016: https:// www.daniels.utoronto.ca/fact-sheet-one-spadina).

Pg 34-35

- Historic photo: Courtesy of the Toronto Public Library TRL T 30609.

- Map: Google Earth.

- Contemporary photo: Kyle Purcell, used with permission.

Pg 36-37

- Photo - Monthly Community Meals: Jeremy Mimnagh, used with permission.

- Photo - Temporary Installations: Sam Carter-Shamai, used with permission.

- Photo - Theatre Space: Sam Carter-Shamai, used with permission.

- Photo - Community Collaborations and Special Events: Becca Gilgan, used with permission.

Pg 38-39

- Historic photo: Thomas Struth, courtesy of MoMA PS1.

- Map: Google Earth.

- Contemporary photo: Image courtesy of MoMA PS1. Photo by Erin Kornfeld \& Erica Leone / Elk Studios LLC.

Pg 40-41

- Photo - M. Wells Dinette Cafe: MoMA PS1 M. Wells Dinette by lulun \& kame, licensed under CC BY 2.0, via Flickr.

- Photo - The Young Architects Program: IMG 6030 by trevor.pratt, licensed under CC BY-NC-SA 2.0, via Flickr

- Photo - Warm Up: MOMA PS1 Warmup by Dan Nguyen, licensed under CC BY 2.0, via Flickr

Pg 42-43

- Historic photo: The Royal Conservatory, used with permission.

- Map: Google Earth.

- Contemporary photo: Sam Carter-Shamai, used with permission.

$\operatorname{Pg} 44-45$

- Photo - Koerner Hall: Eduard Hueber, courtesy of the Royal Conservatory, used with permission.

- Photo - Learning Through the Arts: Tom Arban, courtesy of the Royal Conservatory, used with permission. 


\section{Acknowledgements}

Authored by Sam Carter-Shamai and Claire Nelischer Design by Studio Jaywall

Report production by Dominic Ali

The authors wish to express thanks to the following organizations and individuals who provided information, interviews, and images to assist in the production of this report:

Canadian Centre for Architecture

City of Toronto

Design Exchange

The John H. Daniels Faculty of Architecture, Landscape and Design MoMA PS1

NADAAA

The Theatre Centre

The Royal Conservatory of Music

Daphne Yuen

Anthony Sotomayor

(C) 2016 Ryerson City Building Institute, Ryerson University, Toronto

ryerson.ca/citybuilding

@RyersonCBI 
A New Life for Old City Hall 